\title{
Natural Products as a Source of Inspiration for Novel Inhibitors of Advanced Glycation Endproducts (AGEs) Formation"
}

Authors

Stefaniya Velichkova, Kenn Foubert, Luc Pieters ${ }^{(D)}$

\section{Affiliation}

Natural Products \& Food Research and Analysis (NatuRA), Department of Pharmaceutical Sciences, University of Antwerp, Antwerp, Belgium

Key words

advanced glycation endproducts (AGEs), natural products, medicinal plants

received accepted after revision

published online

December 23, 2020

June 10, 2021

August 2, 2021

Bibliography

Planta Med 2021; 87: 780-802

DOI $\quad 10.1055 / a-1527-7611$

ISSN 0032-0943

(C) 2021. Thieme. All rights reserved.

Georg Thieme Verlag KG, Rüdigerstraße 14,

70469 Stuttgart, Germany

Correspondence

Dr. Stefaniya Velichkova

Natural Products \& Food Research and Analysis (NatuRA), Department of Pharmaceutical Sciences, University of

Antwerp

Universiteitsplein 1, 2610 Antwerp, Belgium

Phone: + 3232652715 , Fax: + 3232652709

stefaniya.velichkova@uantwerpen.be

\section{ABSTRACT}

Protein glycation, a post-translational modification found in biological systems, is often associated with a core defect in glucose metabolism. In particular, advanced glycation endproducts are complex heterogeneous sugar-derived protein modifications implicated in the progression of pathological conditions such as atherosclerosis, diabetic complications, skin diseases, rheumatism, hypertension, and neurodegenerative diseases. Undoubtedly, there is the need to expand the knowledge about antiglycation agents that can offer a therapeutic approach in preventing and treating health issues of high social and economic importance. Although various compounds have been under consideration, little data from clinical trials are available, and there is a lack of approved and registered antiglycation agents. Next to the search for novel synthetic advanced glycation endproduct inhibitors, more and more the efforts of scientists are focusing on researching antiglycation compounds from natural origin. The main purpose of this review is to provide a thorough overview of the state of scientific knowledge in the field of natural products from plant origin (e.g., extracts and pure compounds) as inhibitors of advanced glycation endproduct formation in the period between 1990 and 2019. Moreover, the objectives of the summary also include basic chemistry of AGEs formation and classification, pathophysiological significance of AGEs, mechanisms for inhibiting AGEs formation, and examples of several synthetic anti-AGEs drugs.

\section{Introduction}

Today, age-related chronic inflammatory diseases like type 2 diabetes mellitus and cardiovascular diseases represent major health problems [1]. The prevalence of those conditions is exponentially increasing as the population ages [2]. Therefore, prevention is of the highest importance and has a medical and economic impact. Not surprisingly, future strategies are focusing on the identification of individuals at risk for developing chronic complications using novel biomarkers for pathophysiological pathways (i.e., to improve risk prediction) [2]. Various mechanisms have been proposed to explain the causes for the initiation and progression of chronic diseases, and on a biochemical level, experimental and histological data suggest that protein glycation-formation of AGEs, correlates with many pathological complications [3-5].
The term glycation is defined as the spontaneous, nonenzymatic reaction of glucose or other reducing sugars with an amino group of proteins, lipids, and nucleic acids [6]. Protein glycation occurs predominantly on lysine, arginine, and $\mathrm{N}$-terminal residues of proteins. It involves series of complex reactions, and it is considered a post-translational modification of proteins found in biological systems [6, 7]. In particular, AGEs are complex, heterogeneous, sugar-derived protein modifications that have been implicated in the pathogenesis of diabetic complications, Alzheimer's disease, and the process of normal aging [8-10]. Additionally, important

\footnotetext{
\# Dedicated to Professor Arnold Vlietinck on the occasion of his 80th birthday.
} 


$\begin{array}{ll}\text { ABBREVIATIONS } \\ \text { 3-DG } & \text { 3-deoxyglucosone } \\ \text { ACE } & \text { angiotensin-converting enzyme } \\ \text { AGEs } & \text { advanced glycation end products } \\ \text { AIIRIs } & \text { angiotensin II receptor inhibitors } \\ \text { ALEs } & \text { advanced lipoxidation endproducts } \\ \text { CEL } & \text { N-E-carboxyethyl-L-lysine } \\ \text { CML } & \text { N-E-carboxymethyl-L-lysine } \\ \text { DOLD } & \text { deoxyglucosone-derived lysine dimer } \\ \text { GO } & \text { glyoxal } \\ \text { GODIC } & \text { glyoxal-derived imidazoline crosslink GOLD } \\ & \text { glyoxal-derived lysine dimer } \\ \text { IgG } & \text { immunoglobulin G } \\ \text { IgM } & \text { immunoglobulin M } \\ \text { IL-2 } & \text { interleukin 2 } \\ \text { IL-6 } & \text { interleukin } 6 \\ \text { LDLs } & \text { low-density lipoproteins } \\ \text { MG-H } 1 & \text { N-(5-H-5-methyl-4-imidazolon-2-yl)-L-ornithine } \\ \text { MGO } & \text { methylglyoxal } \\ \text { MODIC } & \text { methylglyoxal derived imidazoline crosslink } \\ \text { MOLD } & \text { methylglyoxal-derived lysine dimer } \\ \text { NF-kB } & \text { nuclear factor kappa light chain enhancer } \\ & \text { of activated B cells } \\ \text { NO } & \text { nitric oxide } \\ \text { PMFs } & \text { polymethoxylated flavonoids } \\ \text { RAGE } & \text { receptor for AGEs } \\ \text { RCS } & \text { reactive carbonyl species } \\ \text { ROS } & \text { reactive oxygen species } \\ \text { TGF- } \beta & \text { transforming growth factor- } \beta \\ \text { TNF- } \alpha & \text { tumor necrosis factor- } \alpha \\ \text { VCAM-1 } & \text { vascular cell adhesion molecule-1 } \\ & \end{array}$

physiological glycating agents apart from glucose are dicarbonyl metabolites, particularly GO, MGO, and 3-DG [11].

The classical pathway (Hodge pathway) for AGEs formation can be generally subdivided into 3 stages: initiation, propagation, and an advanced stage ( $\bullet$ Fig. 1). AGEs formation usually takes several days to several weeks to complete due to the lack of enzymatic catalysis during the process. In the first step (initiation), reducing sugars (aldoses and ketoses) react with amino groups via a nucleophilic addition, resulting in aldimines and ketoimines (Schiff bases). Subsequently, through acid-base catalysis, the unstable and reversible Schiff base undergoes Amadori or Heyns rearrangements, resulting in 1-amino-deoxyketosyl or 2-amino-deoxyaldos-2-yl adducts (relatively stable Amadori or Heyns products) [12-14]. During the propagation phase, the Amadori products can be transformed (within weeks) into reactive dicarbonyl products. They initiate glycation by undergoing further nonoxidative dehydration and rearrangement reactions to dicarbonyl compounds, including 3-DG, GO, and MGO. While 3-DG is formed by nonoxidative rearrangement and hydrolysis of Amadori product ( $\bullet$ Fig. 1), MGO and GO can be produced in several additional pathways (see further). Alternatively, Amadori products can generate amines through metal-ion-mediated catalysis and oxidation, while the glycosyl group is dehydrated to form deoxyglucosone (DG). Further on, these early glycation products are highly prone to oxidative (glycoxidation) and nonoxidative degradation, cleavage, and covalent binding, leading to a heterogeneous group of stable compounds and cross-linking of proteins, commonly called AGEs. In particular, the advanced stage is characterized by intermolecular or intramolecular heterocyclic cross-linking and fragmentation that occurs in the protein molecules, leading to protein denaturation and irreversible damage.

Meanwhile, AGEs can also be formed from Amadori products directly through rearrangement under both oxidative and nonoxidative conditions. In the oxidative pathway (Namiki pathway), the unstable initial products (Schiff bases) can be directly converted to oxoaldehydes (glycoxidation) [15]. Additionally, the Wolff pathway describes the metal-catalyzed autoxidation of reducing sugars that leads to AGEs formation $[16,17]$. The products from both pathways are dicarbonyl intermediates (MGO, GO, 3-DG) and free radicals. Moreover, the oxidation of polyunsaturated fatty acids (lipoxidation pathway) can also lead to GO or MGO formation, apart from the general ALEs. AGEs can be formed by pre- and post-Amadori product reactions, and in such a way that the Amadori product is not a precursor. Therefore, AGEs are generated in both the early and late stages of glycation processes. Nevertheless, the concept of early and advanced glycation adducts simplifies the whole process but ensures a possibility of classifying the different glycation products [6].

\section{AGEs Classification}

Many attempts have been made to classify the diverse group of AGEs. For instance, one approach is based on their fluorescence properties and the presence of cross-linking in their structure ( Fig. 2): fluorescent cross-linked AGEs (pentosidine, crossline, vesperlysine $A-C$ ); nonfluorescent cross-linked AGEs (glucosepane, MOLD, GOLD); and nonfluorescent noncrosslinked AGEs (CML, pyrraline, argpyrimidine) [18]. Another classification is according to the molecular structure of the glycation adduct and the mechanism of AGEs formation ( $\bullet$ Table 1) [6].

Today a variety of AGEs structures have been characterized in different human tissues associated with various pathological conditions ( $\triangleright$ Table 1 ), including pyrraline, pentosidine, crossline, CML, CEL, GOLD, MOLD, methylglyoxal-derived hydroimidazolones, and glucosepane [19-22]. MGO and GO can react with lysine residues to form CEL and CML, respectively, while the three oxoaldehydes can lead to the analogous di-lysyl cross-linked MOLD, GOLD, and DOLD. Among the most studied AGEs that have been detected in a wide range of tissues are pentosidine, CML, and MGO derivatives. They can be considered biomarkers for AGEs formation [23, 24].

\section{Pathophysiological Role of AGEs}

AGEs formation takes place under normal physiological conditions, but the equilibrium can be shifted in a state of hyperglycemia [25]. Therefore, they are referred to sometimes as glycotoxins because they can be toxic to the body when present for a prolonged period [26]. Most AGEs accumulate with age in long-lived 


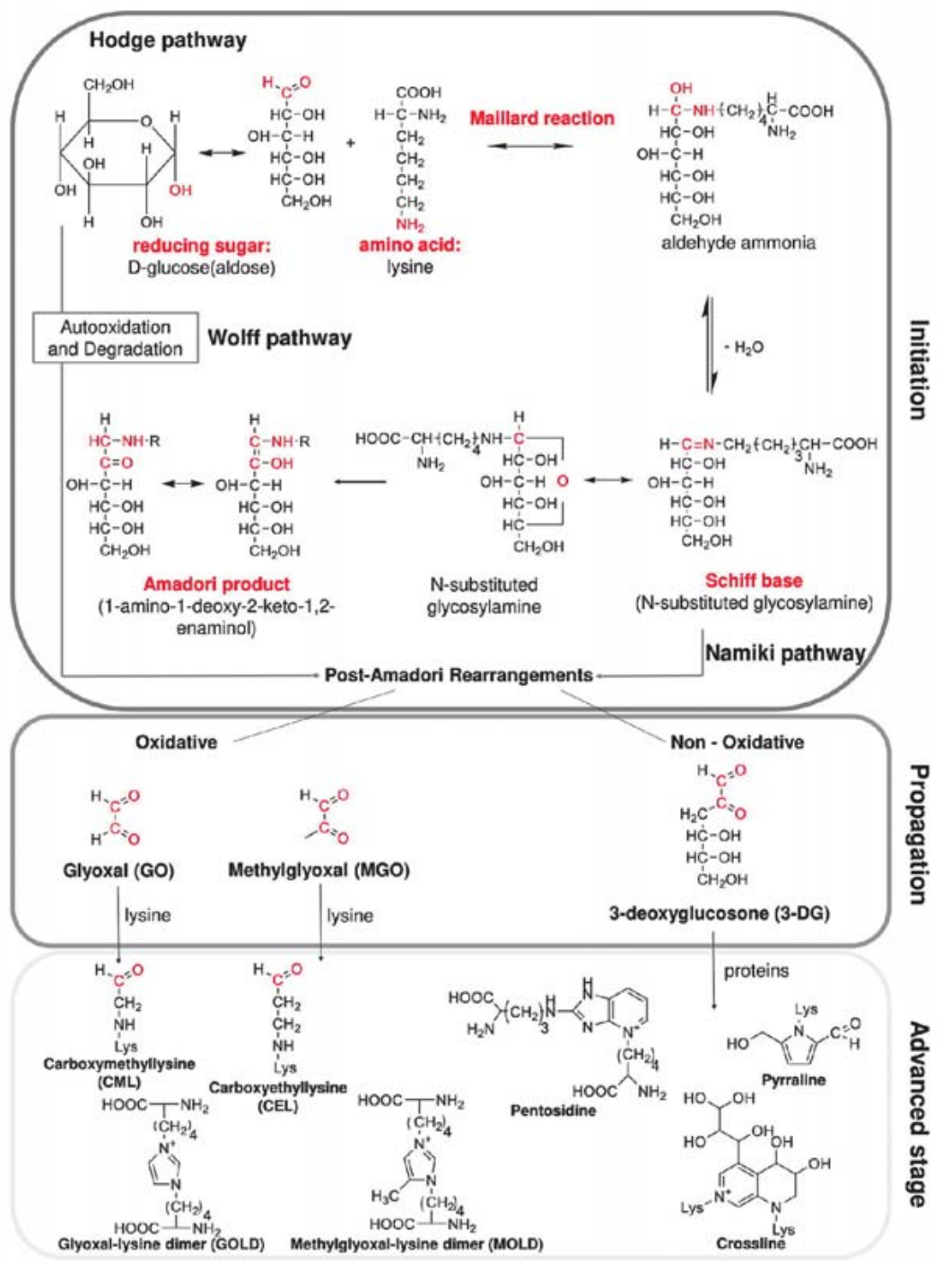

- Fig. 1 General scheme of the Advanced Glycation Endproducts (AGEs) formation pathway (Hodge pathway) going through Schiff base and Amadori product formation. However, AGEs can be formed by pre- and post-Amadori product reactions, and in such a way that the Amadori product is not a precursor. Alternatively, the reactive dicarbonyl species can be formed directly from Schiff base degradation (Namiki pathway) or through the metal-catalyzed autoxidation of reducing sugar (Wolff pathway).

tissue proteins like lens crystallins and collagen due to their slow formation rate $[27,28]$. Despite a belief that AGEs accumulate only on long-lived extracellular proteins, rapid extracellular AGEs formation on short-lived proteins and intracellular AGEs formation by reactive dicarbonyl compounds have recently become major topics of research interest [28]. In general, the pathophysiological effects of AGEs can be related to several mechanisms of action: (i) oxidative stress; (ii) carbonyl stress; and (iii) interaction with RAGE on the cell surface [29-31]. To begin with, oxidative stress can lead to the damage of various cell components and the activation of specific signaling pathways like nuclear factor- $\kappa \mathrm{B}$ (NF- $\kappa \mathrm{B}$ ) ( $\vee$ Fig. 3). In general, the hypothesis of cellular damage (to cardiac muscle and neuronal cells) associated with age-related diseases and explained by excessive oxidative stress was formulated a long time ago. However, novel pharmaceutical targets have been characterized lately, opening new research challenges. A relatively new field of interest is carbonyl stress, an imbalance of RCS production and carbonyl scavenging mechanisms. An important step in the glycation reaction is the generation of reactive intermediate products during all stages and pathways of glycation. For example, Schiff bases are highly prone to oxidation and free radical generation, which lead to the formation of RCS such as GO, MGO, and 3-DG. Compared to ROS, these aldehydes are more stable and diffuse within or even escape from the cell and attach to targets far away from their site of formation. The phenomenon accelerates in diabetes and glycemia. Through the generation of ROS and RCS, AGEs contribute to tissue injury by alteration of extracellular matrix structures through the formation of protein cross-links and 


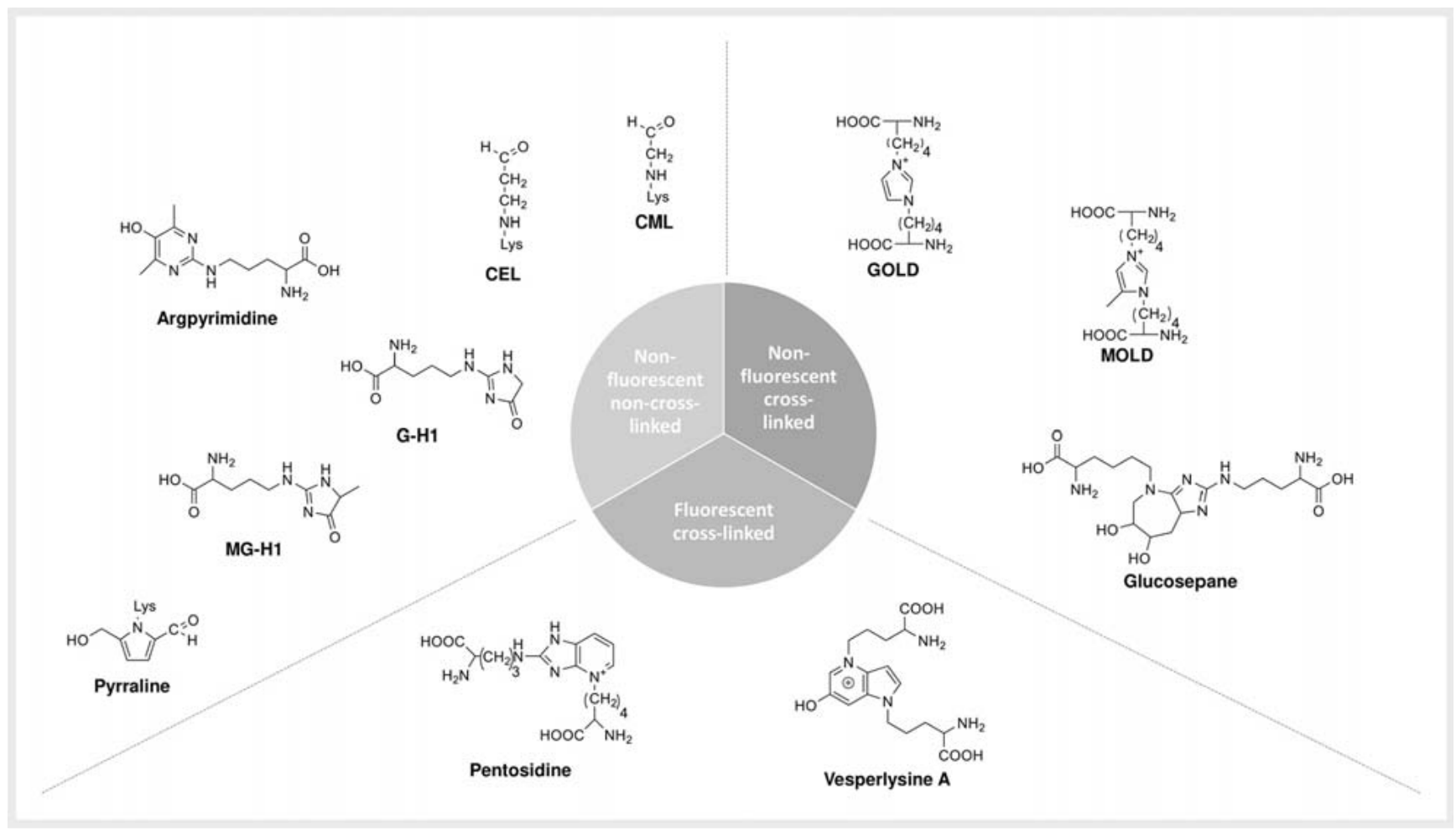

- Fig. 2 AGEs classification based on their fluorescent properties and the presence of cross-linking in the structure, namely, non-fluorescent crosslinked, fluorescent cross-linked and non-fluorescent non-cross-linked AGEs.

- Table 1 Molecular structures and pathophysiological properties of some glycation products.

\begin{tabular}{|c|c|c|c|}
\hline Classification & Glycation product & Pathophysiology & References \\
\hline $\begin{array}{l}\alpha \text {-dicarbonyl } \\
\text { intermediates }\end{array}$ & MGO & $\begin{array}{l}\text { nephropathy, atherosclerosis, tissue injury, } \\
\text { and protein cross-linking }\end{array}$ & {$[45,46,87-89]$} \\
\hline \multirow[t]{3}{*}{$\begin{array}{l}\text { monolysine } \\
\text { adducts }\end{array}$} & $\mathrm{CML}$ & $\begin{array}{l}\text { skin collagen cross-linking, progression of } \\
\text { cardiovascular diseases }\end{array}$ & {$[19,88,90]$} \\
\hline & CEL & $\begin{array}{l}\text { accumulating in tissue proteins, progression of } \\
\text { cardiovascular diseases }\end{array}$ & {$[90,91]$} \\
\hline & pyrraline & plasma proteins and skin collagen cross-linking & {$[20,91]$} \\
\hline \multirow[t]{4}{*}{$\begin{array}{l}\text { imidazolium } \\
\text { crosslinks }\end{array}$} & GOLD (glyoxal-lysine dimer) & $\begin{array}{l}\text { a major crosslink in serum proteins of uremic and } \\
\text { hemodialysis patients }\end{array}$ & {$[92,93]$} \\
\hline & MOLD (methylglyoxal-lysine dimer) & $\begin{array}{l}\text { cross-link formed in lens protein, a major crosslink in } \\
\text { serum proteins of uremic and hemodialysis patients }\end{array}$ & {$[21,92,93]$} \\
\hline & $\begin{array}{l}\text { DOLD (3-deoxyglucasone-derived } \\
\text { lysine dimer) }\end{array}$ & not yet detected in tissue proteins & {$[21,92]$} \\
\hline & glucosepane & $\begin{array}{l}\text { cross-linked AGE in old human collagen and human } \\
\text { eye lenses, associated with stiffness of arteries, } \\
\text { joints, and lenses in diabetes }\end{array}$ & {$[92]$} \\
\hline \multirow[t]{3}{*}{ fluorophores } & argpyrimidine & cataractous lenses & [91] \\
\hline & pentosidine & lens proteins and skin collagen cross-linking & {$[22,88]$} \\
\hline & vesperlysine $A, B, C$ & cross-linked products formation & [94] \\
\hline
\end{tabular}




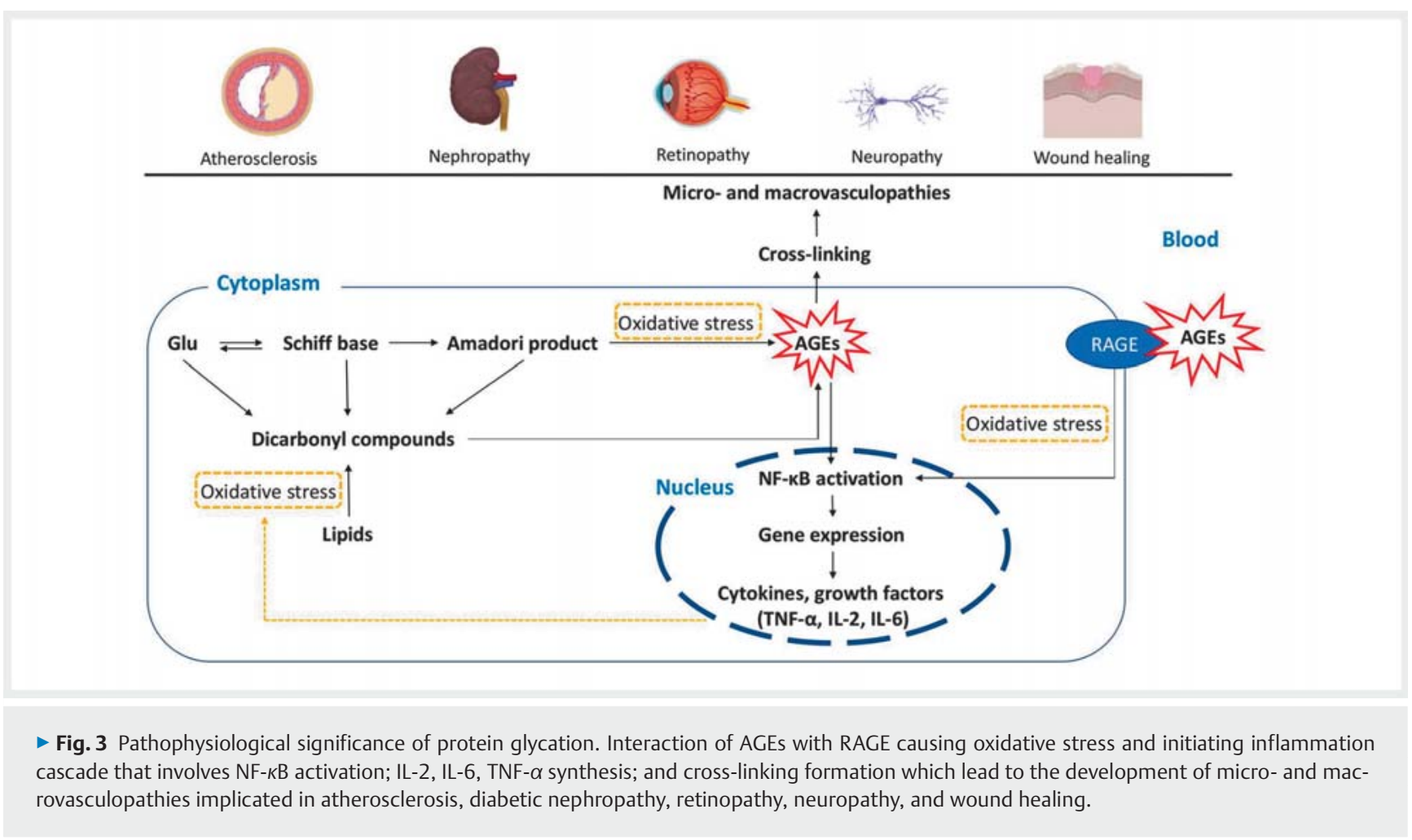

alteration of intracellular short-lived proteins like metabolic enzymes and mitochondrial protein complexes [32]. Inside cells, the impact of glycation is countered by the high turnover and short half-life of many cellular proteins. Long-lived extracellular proteins, however, accumulate glycation adducts with age. Extracellular degraded glycated proteins are recognized by specific receptors [33]. Multiple receptor independent and dependent pathways linking AGEs to cellular and tissue dysfunction have been proposed [34]. So far, it is well-understood that the interaction between AGE-modified proteins and RAGEs on the cell surface induces the overproduction of ROS and inflammatory mediators, which leads to cellular disorder in biological systems [35]. The receptors are weakly expressed in vascular cells, smooth muscle cells, fibroblasts, and monocyte/macrophages. The link between RAGE and its ligands triggers a cascade of intracellular events, followed by the transcription of a range of genes involved in different biological systems, as well as other reactions such as the induction of oxidative stress ( $\triangleright$ Fig. $\mathbf{3}$ ). All of these reactions lead to a series of functional changes that participate in neurological and vascular complications (micro- and macrovasculopathies) in diabetes, metabolic syndrome, etc. $[23,36]$. There is a considerable body of evidence that the formation and accumulation of AGEs are implicated as a major factor in the progression of various pathological conditions, such as atherosclerosis, diabetic retinopathy, nephropathy, neuropathy, wound healing, and Alzheimer's disease (see $>$ Fig. 3).

Hyperglycemia results in an accumulated amount of AGEs in the blood vessels, which induces proliferation of smooth muscle cells, thickening of the intima (plaque formation and sedimentation), and rigidity and stiffness of the vessels. Moreover, AGEs stimulate foam cell formation by lipid and protein glycosylation. The LDLs are not discarded in the normal way and then accumulate in the monocytes to form foam cells. The reason for this is that the LDL receptor does not recognize the glycated LDLs. The AGE-RAGE complex induces atherosclerosis by enhanced expression of VCAM-1 on the endothelial cells and the production of cytokines. As a result, VCAM-1 promotes the adhesion of the monocytes to the endothelial cells. Then, the monocytes differentiate into macrophages that transform into foam cells by lipid uptake. Generally, pathological glycation of collagen is the major cause of tissue dysfunction due to cross-linking that could cause decreased elasticity and increased thickness and rigidity of the vessel lumen. As a result, the vascular damage associated with diabetes is the key for microvascular complications like neuropathy, nephropathy, and retinopathy [37]. The AGE-RAGE complex increases the production of cytokines (IL-2, IL-6) and growth factors $(\mathrm{TNF}-\alpha)(\triangleright$ Fig. 3$)$ that are responsible for the development of macrovascular complications like generalized atherosclerotic plaques. Additionally, during the glycoxidative stress, NF- $\kappa \mathrm{B}$ activates the production of TNF- $\alpha$, which leads to enhanced ROS production; in other words, AGEs formation continues oxidative stress ( $\triangleright$ Fig. 3 ) [32].

Retinopathy is the major cause of blindness in diabetic patients. The accumulation of AGEs leads to thickening of the capillary basement membrane, enhanced permeability of the capillaries, and apoptosis of pericytes. Hyperglycemia stimulates an excessive expression of RAGE on pericytes and endothelial cells, causing deterioration of the pericytes. The loss of pericytes is the clinical expression of retinopathy. Moreover, a high level of AGEs in retinal cells includes the expression of vascular endothelial 


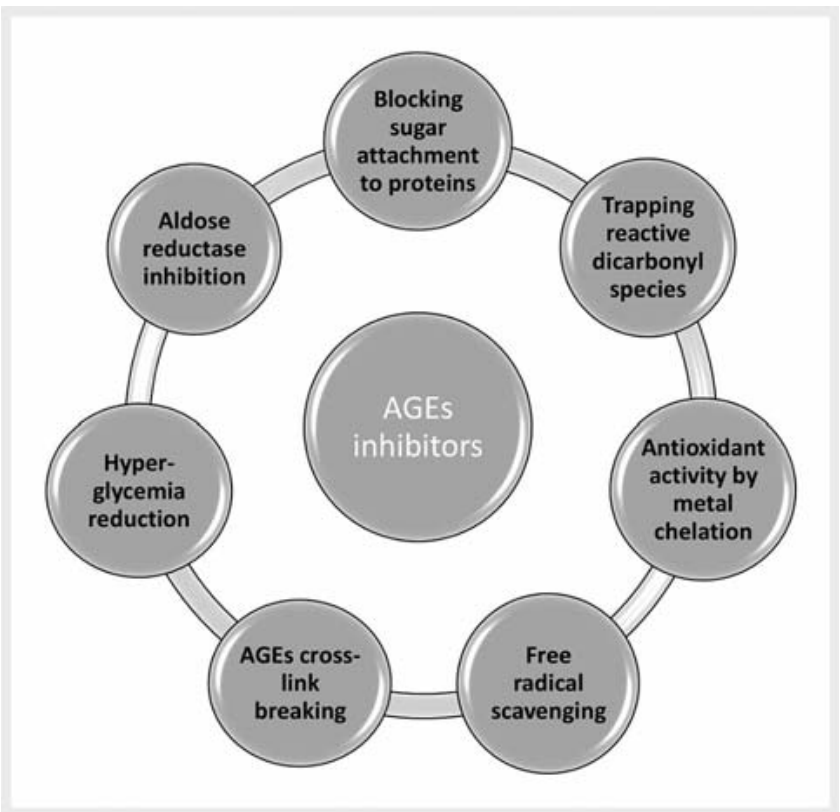

- Fig. 4 Different mechanisms of inhibiting AGEs formation.

growth factor, which destroys the blood-retinal barrier, and microvascular hyper-permeability, which finally leads to blindness or poor vision [38].

Diabetic nephropathy, which is considered the most lifethreatening condition in diabetic patients, is associated with basal membrane thickening and decreased filtration [39]. The sedimentation of proteins in the glomerular space plays a significant role in the reduction of filtration. AGEs stimulate an extreme RAGE expression that encourages cell inflammation signaling pathways, such as NF- $\kappa$ B activation, as well as the generation of cytokines and growth factors. The TGF- $\beta$ increases the synthesis of collagen matrix components, which leads to the greater thickness of the basement membrane, increased vascular permeability, and reduced barrier activity [40]. Further evidence for glomerular injuries comes from immunohistochemical studies that have identified several AGEs such CML, pyrraline, and pentosidine in renal tissues of diabetic patients [41].

In general, diabetes can affect the central, peripheral, and autonomic systems. The manifestation of diabetic neuropathy can be characterized by functional abnormalities (reduced blood flow) and structural changes like axonal degeneration, fiber demyelination, and neuronal apoptosis. Particularly, AGEs react with plasma proteins like IgM and IgG to activate the demyelination of the peripheral neurons. The complex AGE-RAGE induces ROS formation and several intercellular signaling pathways. ROS promotes both AGEs formation and AGEs' quenching of NO. Consequently, the NO level in the cells is decreased, which results in nerve ischemia (lack of oxygen) and then nerve dysfunction [42].

Wound healing in diabetic patients is hindered by the AGERAGE complex, which stimulates the production of pro-inflammatory factors resulting in collagen degradation [43].
The increased number of AGEs can cause extensive cross-linking, oxidative stress, and neuronal cell death representing the neuropathological and biochemical characteristics of Alzheimer's disease, hampering the function of proteins or tissues [44].

\section{Mechanisms of Inhibiting AGEs Formation}

The role of AGEs in the genesis of many pathological conditions has initiated the process of identifying and developing AGEs inhibitors that suppress their formation. For instance, the inhibitory mechanism of AGEs formation ( $\triangleright$ Fig. 4) can be accomplished by blocking the sugar attachment to proteins; attenuating glycoxidation and oxidative stress through trapping or scavenging some intermediates, including reactive dicarbonyls, free radicals, and nitrogen species produced in the process of glycation; and breaking down formed cross-links $[45,46]$. Glycation is a major source of ROS and RCS that are generated by both oxidative (glycoxidative) and nonoxidative pathways [47]. Therefore, potential AGE inhibitors are difficult to distinguish from general antioxidants, such as plant polyphenols. Contrary to the glycation of proteins by glucose, RCS such as MGO and GO exhibit both extracellular and intracellular glycating properties and are involved in nonoxidative glycation reactions and the formation of AGEs in vivo. Glycation inhibitors, whose activity is based on antioxidant properties, may not effectively inhibit nonoxidative protein glycation [48]. Knowing the link between glycation and oxidation, it could be hypothesized that antioxidants might possess antiglycoxidative activities [47]. The investigation and discovery of so-called "AGEs-breakers" also represent a therapeutic approach for lowering the risk of diabetic or other pathogenic complications caused by AGEs formation [45]. So far, a large number of compounds have been reported as inhibitors of glycation and AGE-protein cross-link formation. Additionally, the term "AGEs-breakers" was suggested by Cerami and described compounds that may cleave glycation-derived cross-links and reverse the damaging effects of glycation associated with aging and diseases [49]. Another mechanism of action for the AGEs inhibitors may be related to the key enzyme in the polyol pathway-aldose reductase. During chronic hyperglycemia, excessive glucose uptake in the tissue affects aldose reductase, leading to the reduction of various sugars to sugar alcohol (e.g., glucose to sorbitol) and increased fructose production, and, consequently, active formation of RCS [50]. Alternatively, any inhibitors of the enzyme aldose reductase can be considered as potential agents against AGEs formation.

\section{AGEs Inhibitors}

Today, there is an increased interest in agents with antiglycation activity that could play a key role in the prevention and amelioration of AGE-mediated health problems. The currently known AGEs inhibitors can be generally divided into 2 groups: synthetic compounds and natural products.

\section{Synthetic compounds}

According to a previous review that investigated the current clinical therapies with anti-AGEs effects, the applied agents can be summarized in several groups ( $\bullet$ Table 2 ) [28]. The inhibition of 
- Table 2 Synthetic inhibitors of AGEs formation based on their mechanism of action or their chemical structure.

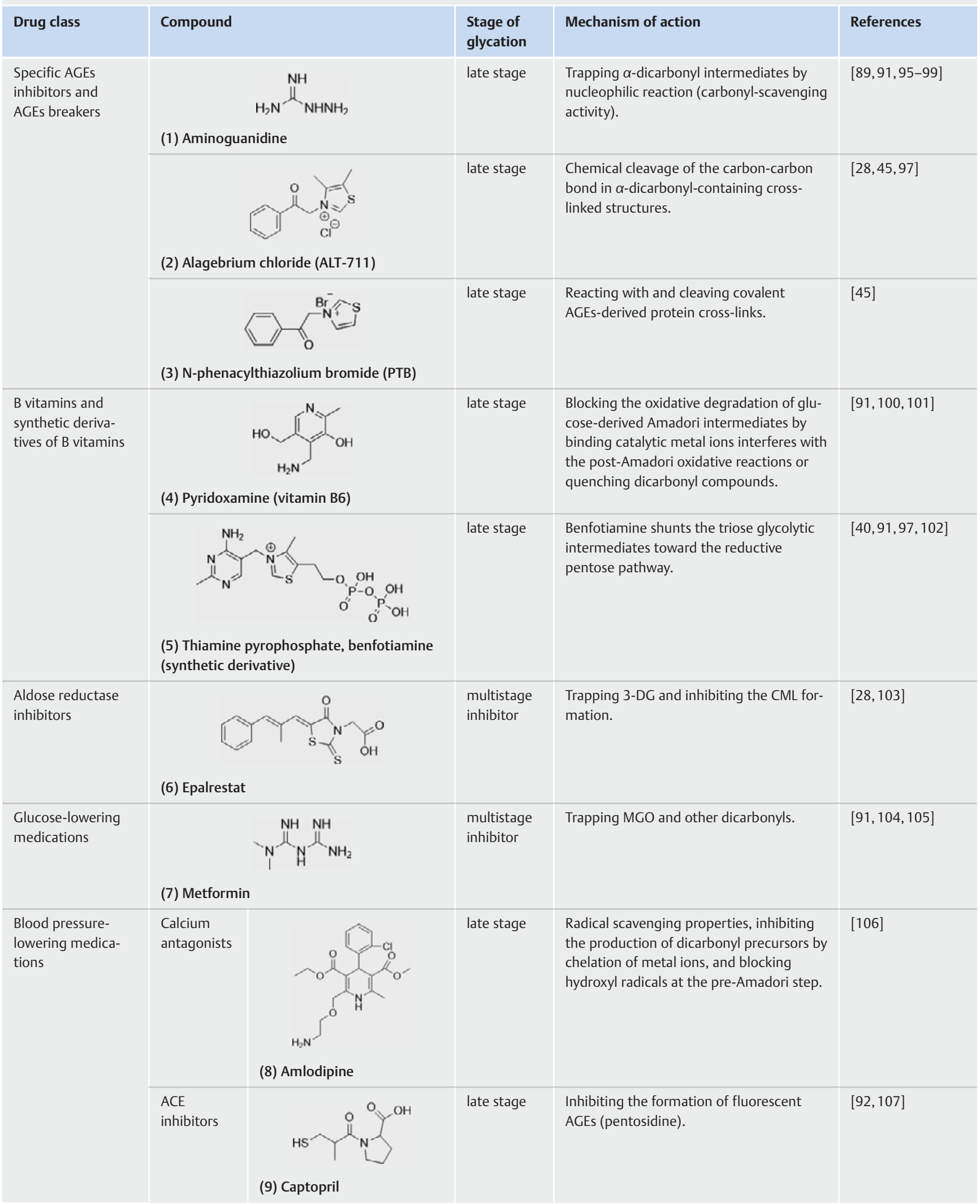


- Table 2 Continued

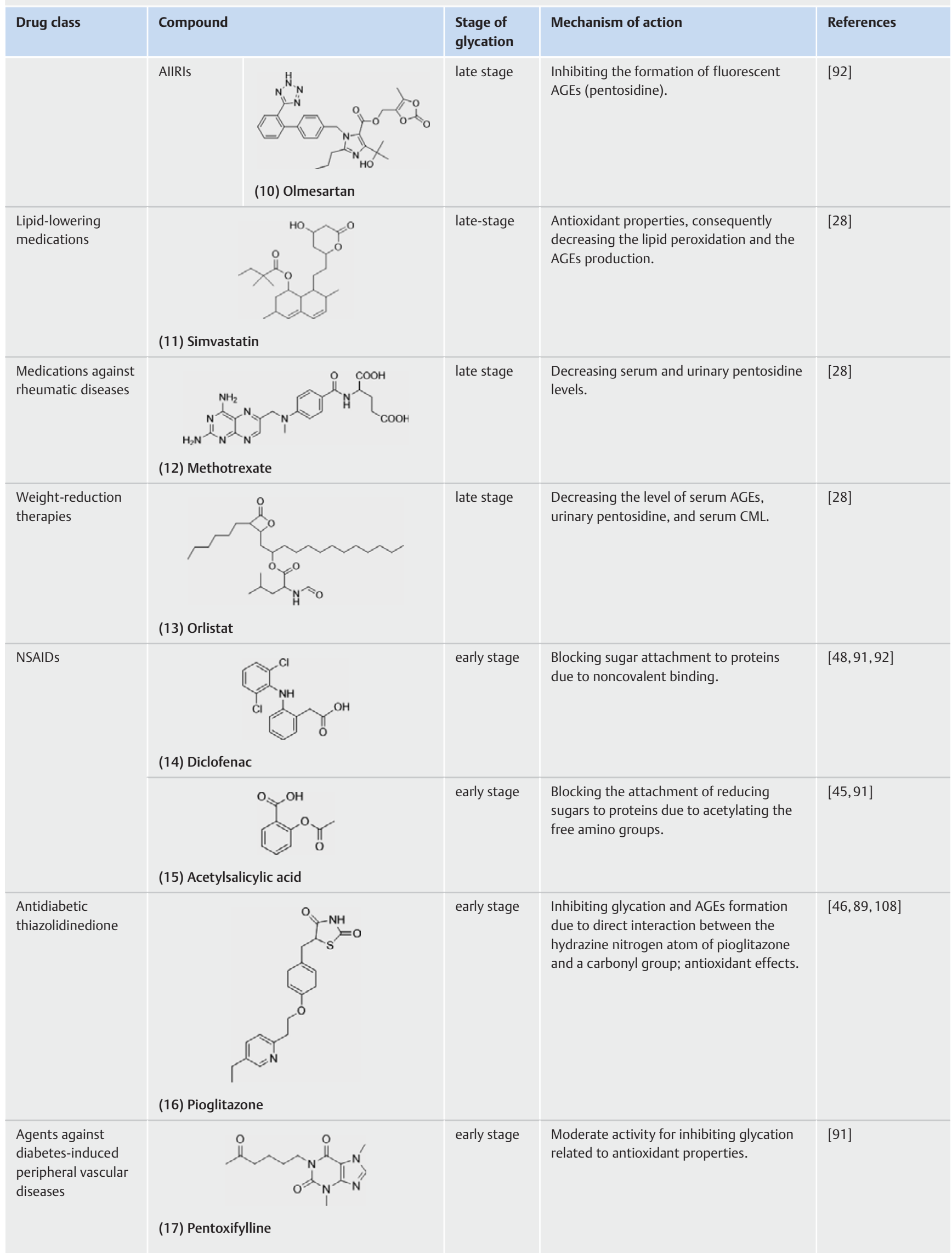




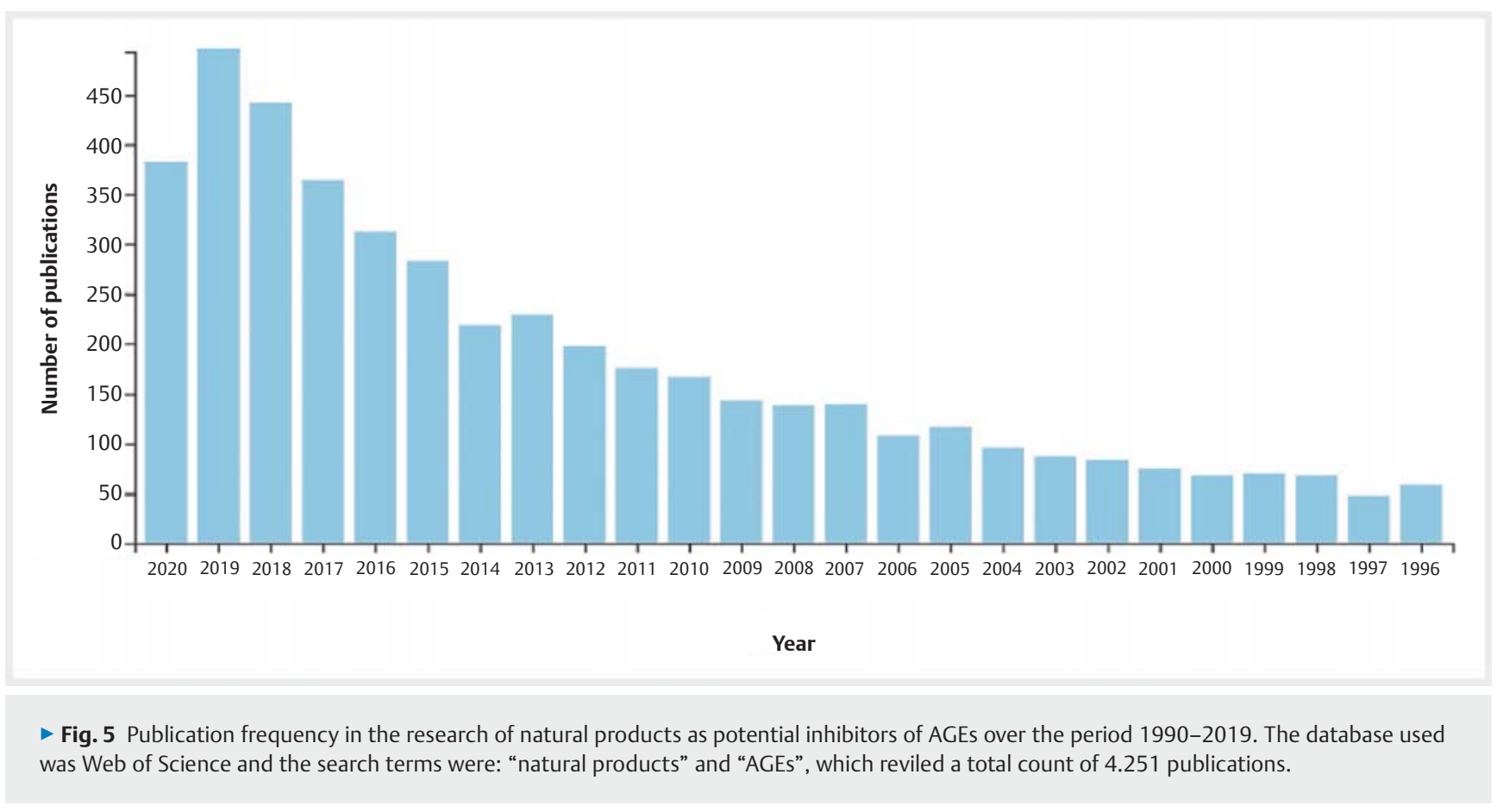

free radical generation, which is derived from glycation processes and inhibition of protein modification, is considered a mechanism of antiglycation activity. Much data have shown that typical antioxidants/nutrients such as (5) vitamin B1 (thiamine) and (4) B6 (pyridoxamine) inhibit in vitro and in vivo AGEs formation [51]. Another preventive or therapeutic approach is to use nucleophilic anti-RCS molecules such as (1) aminoguanidine, pyridoxamine, or (7) metformin. They could inhibit AGEs, remove RCS, and prevent the interaction of AGEs with RAGE. Despite the reported inhibitory capacity against AGEs formation, many synthetic inhibitors have been withdrawn from clinical trials due to relatively low efficacy, poor pharmacokinetics, and unsatisfactory safety [52].

\section{Natural products}

Current studies attempt to search for effective phytochemical compounds from dietary plants, fruits, and herbal medicines to inhibit AGEs formation [53]. In the past 3 decades, there has been a significant increase in the anti-AGEs agents from natural origin. The rate of scientific publications tripled during this time. In the current review, the references were selected by a search of papers retrieved using Web of Science for the period 1990-2019 and the keywords "natural products" and "AGEs" ( $>$ Fig. 5).

Considering the toxic or side effects of synthetic molecules in clinical trials, natural products can be more promising candidates as potent AGEs inhibitors. Phytochemicals exhibit several antiglycation mechanisms, including effects on glucose metabolism, amelioration of oxidative stress, scavenging of dicarbonyl species, and up/down-regulation of gene expression [54]. So far, some plant extracts and their phenolic ingredients have been evaluated for activity against AGEs formation and also for their antioxidant activity [55]. Therefore, natural products with strong inhibitory properties on AGEs formation have great potential for further in- vestigation as preventive drugs against AGE-associated diseases and disorders [45]. However, it remains unknown whether phytochemicals possess protective effects against glycotoxin-induced damage. While the anti-AGEs activity of a wide variety of synthetic molecules has already been evaluated, the chemodiversity of natural products such as secondary metabolites of vegetal origin still needs to be thoroughly explored [56]. Many plant products and their active constituents have been reported for the prevention and treatment of various pathological conditions in the human body: various plant extracts ( $\triangleright$ Table 3 ), fractions, or pure compounds ( $\vee$ Table 4 ) have been heavily tested for inhibiting AGEs formation [26].

\section{Plant extracts}

Chrysanthemum morifolium Ramat. (Asteraceae) contains a large amount of (27) chlorogenic acid, flavonoid glucoside, and aglycone varieties-for example, (38) apigenin. Chrysanthemum indicum L. (Asteraceae) is a rich source of (24) caffeic acid, luteolin, and (44) kaempferol. The 2 Chrysanthemum species extracts demonstrated strong inhibition of AGEs formation, in particular, CML and pentosidine in the BSA/glucose (fructose) assay [57]. The inhibitory effects of Chrysanthemum extracts at a concentration of $5 \mathrm{mg} / \mathrm{ml}$ were stronger than aminoguanidine at a concentration of $1 \mathrm{mM}$, which was used as a positive control.

The ethyl acetate-soluble fraction of the stem and leaves extract of Erigeron annuus L. (Asteraceae) contains quinic acid derivatives such as 3,5-di-O-caffeoyl-epi-qunic acid, which showed an $\mathrm{IC}_{50}$ of $6.06 \mu \mathrm{M}$ in the BSA/glucose assay (while the $\mathrm{IC}_{50}$ of aminoguanidine was $961 \mu \mathrm{M}$ ) and prevented opacification of rat lenses [58].

Cinnamon (Cinnamomum verum J. Presl, Lauraceae), a traditional spice, has been shown to attenuate the symptoms of meta- 
- Table 3 Medicinal plant extracts inhibiting AGEs formation.

\begin{tabular}{|c|c|c|c|}
\hline Plant & Extract & Antiglycation activity & Reference \\
\hline $\begin{array}{l}\text { Allium sativum } \\
\text { skin }\end{array}$ & $\begin{array}{l}50 \% \text { ethanolic } \\
\text { extract }\end{array}$ & $\begin{array}{l}\text { Inhibiting AGEs formation in an in vitro BSA/fructose assay. } \\
\text { Strong antioxidant and free-radical scavenging properties. }\end{array}$ & {$[26,59]$} \\
\hline $\begin{array}{l}\text { Alpinia zerumbet } \\
\text { rhizome }\end{array}$ & Hexane & $\begin{array}{l}\text { Inhibiting the Amadori products formation and trapping reactive } \\
\text { dicarbonyl compounds. }\end{array}$ & [109] \\
\hline $\begin{array}{l}\text { Apocynum venetum L. (Apocynaceae) } \\
\text { leaves }\end{array}$ & water & $\begin{array}{l}\text { Antioxidant properties and protection against glucose-mediated } \\
\text { protein modification in vitro. }\end{array}$ & {$[110,111]$} \\
\hline $\begin{array}{l}\text { Aralia taibaiensis } \\
\text { root bark }\end{array}$ & n-butanol & $\begin{array}{l}\text { Inhibiting AGEs formation in vitro: BSA/glucose, Gk-peptide/ } \\
\text { ribose, and hemoglobin- } \delta \text { glucose assay. }\end{array}$ & [66] \\
\hline $\begin{array}{l}\text { Astragalus membranaceus L. (Fabaceae) } \\
\text { roots }\end{array}$ & methanol & $\begin{array}{l}\text { Hypoglycemic effect, decreasing the aldose reductase and } \\
\text { increasing the insulin level. Additionally, inhibiting the CML and } \\
\text { pentosidine formation. }\end{array}$ & [112] \\
\hline $\begin{array}{l}\text { Calendula officinalis L. (Asteraceae) } \\
\text { whole plant }\end{array}$ & methanol & $\begin{array}{l}\text { Inhibiting protein glycation in BSA/glucose in vitro assay, potent } \\
\text { antioxidant activity. }\end{array}$ & [113] \\
\hline $\begin{array}{l}\text { Camellia sinensis } \\
\text { leaves }\end{array}$ & water & $\begin{array}{l}\text { Inhibiting AGEs formation in the BSA/MGO and BSA/ribose } \\
\text { models by trapping } \alpha \text {-dicarbonyl compounds. Reducing the } \\
\text { post-prandial hyperglycemia. }\end{array}$ & {$[26,62]$} \\
\hline $\begin{array}{l}\text { Chrysanthemum sp. } \\
\text { flowers }\end{array}$ & water & $\begin{array}{l}\text { Inhabiting CML and pentosidine formation in an in vitro BSA/ } \\
\text { glucose (fructose) assay by free radical and metal scavenging. }\end{array}$ & [57] \\
\hline $\begin{array}{l}\text { Cinnamomum verum } \\
\text { bark }\end{array}$ & ethyl acetate & $\begin{array}{l}\text { Inhibiting CML and pentosidine formation. Mimicking insulin } \\
\text { activity. }\end{array}$ & {$[26,54]$} \\
\hline $\begin{array}{l}\text { Citrus sinensis seeds; } \\
\text { Citrus reticulata } \times \text { C. sinensis peels } \\
\text { C. reticulata } \times \text { Citrus paradisis peels }\end{array}$ & $\begin{array}{l}\text { water; } \\
80 \% \text { methanol }\end{array}$ & $\begin{array}{l}\text { Inhibiting AGEs formation in BSA/glucose assay; HSA/MGO assay. } \\
\text { Potent free radical scavenging activity. }\end{array}$ & {$[114,115]$} \\
\hline $\begin{array}{l}\text { Cuminum cyminum } \\
\text { seeds }\end{array}$ & methanol & Inhibiting AGEs formation in BSA/fructose assay. & [67] \\
\hline $\begin{array}{l}\text { Curcuma longa L. (Zingiberaceae) } \\
\text { rhizome }\end{array}$ & methanol & $\begin{array}{l}\text { Inhibiting free radicals and } \mathrm{HbA}_{1 c} \text { formation; antioxidant effect, } \\
\text { hypoglycemic effect, and preventing lipid peroxidation. }\end{array}$ & {$[116,117]$} \\
\hline $\begin{array}{l}\text { Empetrum nigrum L. (Ericaceae) } \\
\text { fruit }\end{array}$ & $80 \%$ ethanol & $\begin{array}{l}\text { Inhibiting the formation of fluorescent AGEs in a concentration- } \\
\text { dependent manner, potent radical scavenging activity. }\end{array}$ & [118] \\
\hline $\begin{array}{l}\text { Erigeron annuus } \\
\text { leases and stems }\end{array}$ & methanol & $\begin{array}{l}\text { Inhibition of RLAR (rat lens aldose reductase), AGEs formation, } \\
\text { AGEs/BSA cross-linking, and cataractogenesis. }\end{array}$ & [58] \\
\hline $\begin{array}{l}\text { Garcinia mangostana } \\
\text { pericarp }\end{array}$ & water & Inhibiting the formation of pentosidine. & [63] \\
\hline $\begin{array}{l}\text { Garcinia subelleptica (Clusiaceae) } \\
\text { leaves }\end{array}$ & ethyl acetate & $\begin{array}{l}\text { Inhibiting protein glycation in several in vitro models: BSA/ } \\
\text { glucose experiment, fructosamine adduct, and } \alpha \text {-dicarbonyl } \\
\text { compounds formation. }\end{array}$ & [82] \\
\hline $\begin{array}{l}\text { Glycyrrhiza glabra L. (Fabaceae) } \\
\text { roots }\end{array}$ & methanol & $\begin{array}{l}\text { Inhibiting AGEs formation through radical scavenging properties. } \\
\text { Antioxidant and hypoglycemic activity. }\end{array}$ & [119] \\
\hline $\begin{array}{l}\text { Hypericum perforatum L. (Hypericaceae) } \\
\text { aerial part }\end{array}$ & methanol & $\begin{array}{l}\text { Free radical scavenging activity, inhibiting lipid peroxidation, } \\
\text { and inhibiting the advanced glycation in a BSA/glucose assay. }\end{array}$ & [120] \\
\hline Ilex paraguariensis leaves and stems & water & $\begin{array}{l}\text { Inhibition of the free-radical-mediated conversion of Amadori } \\
\text { products to AGEs. }\end{array}$ & {$[26,60]$} \\
\hline $\begin{array}{l}\text { Juglans regia L. (Juglandaceae) } \\
\text { bark }\end{array}$ & methanol & $\begin{array}{l}\text { Inhibiting protein glycation in BSA/glucose in in vitro assay, } \\
\text { antioxidant activity. }\end{array}$ & [113] \\
\hline $\begin{array}{l}\text { Knoxia valerianoides Thovel ex Pitards } \\
\text { (Rubiaceae) } \\
\text { root }\end{array}$ & methanol & $\begin{array}{l}\text { In vitro inhibition of AGEs formation in BSA/fructose and glucose } \\
\text { assay, and inhibition of rat lens aldose reductase activity. }\end{array}$ & {$[99,121]$} \\
\hline $\begin{array}{l}\text { Matricaria recutita L. (Asteraceae) } \\
\text { leaves }\end{array}$ & $\begin{array}{l}70 \% \text { methanol } \\
\text { extract }\end{array}$ & $\begin{array}{l}\text { Potent inhibition on the rat lens aldose reductase, AGEs forma- } \\
\text { tion, and reactive oxygen species. }\end{array}$ & {$[122]$} \\
\hline
\end{tabular}


- Table 3 Continued

\begin{tabular}{|c|c|c|c|}
\hline Plant & Extract & Antiglycation activity & Reference \\
\hline $\begin{array}{l}\text { Melissa officinalis L. (Lamiaceae) } \\
\text { leaves }\end{array}$ & water & $\begin{array}{l}\text { Inhibiting the pentosidine formation in BSA/fructose model. } \\
\text { Improving tissue damage in blood vessels and skin elasticity. }\end{array}$ & [123] \\
\hline $\begin{array}{l}\text { Mentha arvensis L. (Lamiaceae) } \\
\text { leaves }\end{array}$ & water & $\begin{array}{l}\text { Reduction of fructosamine formation, dicarbonyl compounds } \\
\text { formation, and glycated albumin; free radical scavenging } \\
\text { activity. }\end{array}$ & {$[124]$} \\
\hline $\begin{array}{l}\text { Nigella sativa L. (Ranunculaceae) } \\
\text { Seeds }\end{array}$ & water & Scavenging reactive carbonyl and oxygen species. & [125] \\
\hline Origanum majorana leaves & methanol & $\begin{array}{l}\text { Inhibiting AGEs formation in vitro (BSA/glucose assay, BSA/MGO } \\
\text { assay, Amadori screening assay, glycation of hemoglobin) and in } \\
\text { streptozotocin-induced diabetic rats. }\end{array}$ & {$[64]$} \\
\hline $\begin{array}{l}\text { Panax ginseng L. (Araliaceae) } \\
\text { root }\end{array}$ & $\begin{array}{l}\text { different sol- } \\
\text { vents: water, } \\
70 \% \text { ethanol, } \\
55 \% \text { ethanol }\end{array}$ & Reducing AGEs formation through alleviating oxidative stress. & {$[45,126]$} \\
\hline $\begin{array}{l}\text { Polygonum multiflorum Thunb. } \\
\text { (Polygonaceae) } \\
\text { root }\end{array}$ & $80 \%$ ethanol & $\begin{array}{l}\text { Scavenging free radicals, inhibiting lipid peroxidation, } \\
\text { and protein glycation. }\end{array}$ & [127] \\
\hline $\begin{array}{l}\text { Punica granatum L. (Lythraceae) } \\
\text { fruit }\end{array}$ & fruit juice & $\begin{array}{l}\text { Antiglycation effect through inhibiting the } \alpha \text {-amylase and } \\
\alpha \text {-glucosidase, and metal chelating activity. }\end{array}$ & {$[128,129]$} \\
\hline $\begin{array}{l}\text { Rhus verniciflua Stokes. (Anacardiaceae) } \\
\text { bark }\end{array}$ & ethanol & $\begin{array}{l}\text { Inhibiting aldose reductase and AGEs formation in a BSA/glucose } \\
\text { assay, potent antioxidant activity. }\end{array}$ & {$[130]$} \\
\hline $\begin{array}{l}\text { Rosmarinus officinalis } \\
\text { leaves }\end{array}$ & $\begin{array}{l}50 \% \text { ethanolic } \\
\text { extract }\end{array}$ & $\begin{array}{l}\text { Inhibiting AGEs formation in an in vitro BSA/fructose assay. } \\
\text { Potent antioxidant and antiglycation activity. }\end{array}$ & $\begin{array}{l}{[26,59,} \\
61]\end{array}$ \\
\hline $\begin{array}{l}\text { Solanum lycopersicum L. (Solanaceae) } \\
\text { fruit }\end{array}$ & tomato paste & $\begin{array}{l}\text { Inhibiting glucose autoxidation and trapping reactive dicarbonyl } \\
\text { compounds. }\end{array}$ & $\begin{array}{l}{[26,54,} \\
131]\end{array}$ \\
\hline $\begin{array}{l}\text { Thymus vulgaris } \\
\text { whole plant }\end{array}$ & methanol & $\begin{array}{l}\text { Inhibiting AGEs formation in a BSA in vitro model; fructosamine } \\
\text { formation detected through the reduction of NBT. }\end{array}$ & {$[65]$} \\
\hline $\begin{array}{l}\text { Trigonella foenum-graeceum L. } \\
\text { (Fabaceae) } \\
\text { seeds }\end{array}$ & $\begin{array}{l}70 \% \text { ethanolic } \\
\text { extract }\end{array}$ & $\begin{array}{l}\text { Hypoglycemic and antioxidant effect, decreasing the lipid } \\
\text { peroxidation. }\end{array}$ & {$[132]$} \\
\hline $\begin{array}{l}\text { Vaccinium spp. (Ericaceae) } \\
\text { leaves }\end{array}$ & ethanol & $\begin{array}{l}\text { Inhibiting Amadori product formation and trapping reactive } \\
\text { dicarbonyl compounds. }\end{array}$ & [133] \\
\hline $\begin{array}{l}\text { Vitis vinifera L. (Vitaceae) } \\
\text { skin }\end{array}$ & water & Scavenging free radicals and dicarbonyl species. & {$[134]$} \\
\hline
\end{tabular}

bolic syndrome such as insulin resistance, hyperglycemia, increased protein glycation, and inflammation. It was found that the ethyl acetate extract from the bark containing (33) catechin, (34) epicatechin, and procyanidin B2 inhibited CML and pentosidine formation. Additionally, the presence of catechins was proven to reduce MGO to the physiological level $[26,54]$.

S-ethylcysteine and S-propylcysteine in garlic (Allium sativum L., Amaryllidaceae) extract are strong antioxidants and free radical scavengers, inhibiting CML formation and the plasma $\mathrm{HbA}_{1 \mathrm{c}}$ (glycated hemoglobin) $[26,45]$. In an in vitro BSA/fructose model, the $\mathrm{IC}_{50}$ of the extract was $16.8 \mu \mathrm{g} / \mathrm{ml}$ and lower than that of aminoguanidine at $27.7 \mu \mathrm{g} / \mathrm{ml}$ [59].

Ilex paraguariensis A. (Aquifoliaceae) (maté) contains a high level of antioxidants that have been proven in in vitro models to inhibit the second phase of the glycation reaction, namely, the free radical-mediated conversion of Amadori products to AGEs [26,
45]. In another study, it was shown that $I$. paraguariensis and its main component, chlorogenic acid, inhibited fructose formation of AGEs with amino acids at conditions compatible with those in the digestion system. The value for the maté tea was $83 \%$ inhibition at $50 \mu \mathrm{g} / \mathrm{ml}$ concentration, and for caffeic and chlorogenic acid, the $\mathrm{IC}_{50}$ was $0.9 \mathrm{mM}$ [60].

Rosmarinus officinalis L. (Lamiaceae), which mainly contains (21) rosmarinic acid, (22) carnosic acid, and carnosol, possesses antioxidant activity and antiglycation properties comparable to aminoguanidine [26]. An in vitro BSA/glucose model revealed that rosmarinic acid and carnosic acid at $400 \mu \mathrm{g} / \mathrm{ml}$ inhibit fluorescent AGEs by $90 \%$, and CML and CEL by $82.7 \%$ and $75.2 \%$ and $71.4 \%$ and $64.2 \%$, respectively. Moreover, the addition of $400 \mu \mathrm{g} / \mathrm{ml}$ rosmarinic acid and carnosic acid inhibited fluorescent AGEs by more than $90 \%$, both in the BSA/GO and BSA/MGO models; the forma- 
- Table 4 Pure compounds inhibiting AGEs formation presented according to the classification of plant secondary metabolites.

\begin{tabular}{|c|c|c|c|}
\hline Classification & Compound & Antiglycation activity & Reference \\
\hline Stilbenes & (18) resveratrol & $\begin{array}{l}\text { Inhibiting AGEs formation in BSA/fructose, BSA/MGO, arginine/MGO } \\
\text { models. A competitive inhibitor of } \alpha \text {-amylase and } \alpha \text {-glucosidase. }\end{array}$ & [135] \\
\hline \multirow[t]{2}{*}{ Chalcones } & (19) curcumin & $\begin{array}{l}\text { Inhibiting AGEs formation through trapping MGO, modulating the RAGE } \\
\text { expression, and interfering with the NF- } \kappa \text { B pathway. }\end{array}$ & {$[69]$} \\
\hline & (20) phloridzin & $\begin{array}{l}\text { Inhibiting the absorption of glucose in the small intestines and the renal } \\
\text { resorption, resulting in an overall decrease of hyperglycemia in animal } \\
\text { models. Additional anti-inflammatory activity, antioxidant properties, and } \\
\text { anti-AGEs effect in BSA/glucose in vitro model. }\end{array}$ & {$[136,137]$} \\
\hline \multirow[t]{7}{*}{ Phenolic acids } & $\begin{array}{l}\text { (21) rosmarinic acid, } \\
\text { (22) carnosic acid }\end{array}$ & $\begin{array}{l}\text { Efficiently inhibit AGEs formation in part by decreasing glycation and by } \\
\text { reducing the level of reactive precursors (such as methylglyoxal) for } \\
\text { glycation. }\end{array}$ & {$[61]$} \\
\hline & $\begin{array}{l}\text { (23) 7-O-galloyl-D- } \\
\text { sedoheptulose }\end{array}$ & $\begin{array}{l}\text { Reduced renal glucose, AGEs formation, and oxidative stress in diabetic } \\
\text { rats, showing a beneficial effect on the early stages of diabetic kidney } \\
\text { disease. }\end{array}$ & [73] \\
\hline & (24) caffeic acid & $\begin{array}{l}\text { Inhibiting AGEs formation in the in vitro BSA/glucose model, decrease the } \\
\text { expression of proinflammatory mediators. In general, prevents and delays } \\
\text { vascular dysfunction in diabetes. }\end{array}$ & [138] \\
\hline & (25) ellagic acid & $\begin{array}{l}\text { Preventing in vivo accumulation of AGEs (CML) and ameliorating renal } \\
\text { changes in diabetic rats. }\end{array}$ & {$[139,140]$} \\
\hline & (26) vanillic acid & $\begin{array}{l}\text { Inhibiting reactive dicarbonyl intermediates (MGO), ROS formation, and } \\
\mathrm{CML} \text { formation, and consequently, preventing the development of diabetic } \\
\text { neuropathy. }\end{array}$ & [141] \\
\hline & (27) chlorogenic acid & $\begin{array}{l}\text { Inhibiting the AGEs cross-linking to collagen in an AGE-ELISA assay and } \\
\text { dicarbonyl intermediates (MGO). }\end{array}$ & [142] \\
\hline & (28) ferulic acid & $\begin{array}{l}\text { Preventing glucose-, fructose-, and ribose-induced protein glycation, } \\
\text { as well as MGO-induced protein glycation and oxidative protein damage } \\
\text { in BSA. }\end{array}$ & [143] \\
\hline Kavalactones & $\begin{array}{l}\text { (30) kawain and } \\
\text { methysticine }\end{array}$ & Inhibiting protein glycation in BSA/glucose assay. & [74] \\
\hline Coumarins & (31) umbelliferone & $\begin{array}{l}\text { Inhibiting } \alpha \text {-glucosidase and the pancreatic amylase; as a result, decreas- } \\
\text { ing the postprandial hyperglycemia. Inhibiting } \alpha \text {-dicarbonyl compounds } \\
\text { formation. }\end{array}$ & [144] \\
\hline \multirow[t]{4}{*}{ Flavanols } & (33) $(+)$-catechin & $\begin{array}{l}\text { Greater antiglycation activity due to carbonyl scavenging and antioxidant } \\
\text { activity. }\end{array}$ & [111] \\
\hline & (34) (-)-epicatechin & Trapping ROS and RCS (e.g., MGO). & {$[145]$} \\
\hline & $\begin{array}{l}\text { (35) (-)-epicatechin } \\
\text { gallate }\end{array}$ & $\begin{array}{l}\text { Suppressing the carbonylation and the formation of amyloid cross- } \beta \\
\text { structures of BSA and the AGEs formation through a BSA/fructose model, } \\
\text { additionally trapping MGO. }\end{array}$ & [146] \\
\hline & $\begin{array}{l}\text { (36) (-)-epigallocatechin- } \\
\text { 3-gallate }\end{array}$ & $\begin{array}{l}\text { Decreasing the AGE-stimulated gene expression and production of TNF- } \alpha \text {, } \\
\text { and AGE-mediated activation of NF- } \mathrm{kB} \text {. }\end{array}$ & [147] \\
\hline \multirow[t]{4}{*}{ Flavones } & (37) luteolin & $\begin{array}{l}\text { Potent inhibitor on the early stage of protein glycation ( } \delta \text {-Glu assay), } \\
\text { preventing the } \mathrm{HbA}_{1 \mathrm{c}} \text { formation. }\end{array}$ & [47] \\
\hline & (38) apigenin & $\begin{array}{l}\text { Inhibiting AGEs formation through trapping MGO, suppressing the } \\
\text { production of ROS and inflammatory cytokines and adhesion molecules. }\end{array}$ & [148] \\
\hline & (39) diosmin & $\begin{array}{l}\text { Decreasing glycosylated hemoglobin and increasing hemoglobin and } \\
\text { plasma insulin. }\end{array}$ & [149] \\
\hline & (40) vitexin & $\begin{array}{l}\text { Inhibiting AGEs formation in an in vitro BSA/glucose and BSA/MGO assays } \\
\text { because of trapping dicarbonyl intermediates and free radical scavenging } \\
\text { capacity. }\end{array}$ & [150] \\
\hline
\end{tabular}


- Table 4 Continued

\begin{tabular}{|c|c|c|c|}
\hline Classification & Compound & Antiglycation activity & Reference \\
\hline \multirow[t]{3}{*}{ Flavanones } & (41) naringenin & Inhibiting AGEs formation in an in vitro BSA/MGO assay. & {$[151]$} \\
\hline & (42) plantagoside & $\begin{array}{l}\text { Inhibiting protein glycation and, in physiological conditions, protein cross- } \\
\text { linking glycation. }\end{array}$ & {$[78]$} \\
\hline & (43) liquiritin & $\begin{array}{l}\text { Increasing the AGEs-reduced superoxide dismutase activity, decreasing } \\
\text { RAGE expression, and blocking NF- } \kappa \text { B activation. Consequently, has a } \\
\text { protective effect on AGEs-induced endothelial dysfunction. }\end{array}$ & {$[152]$} \\
\hline \multirow[t]{5}{*}{ Flavonols } & (44) kaempferol & Effect on the intermediate stage of AGEs formation by trapping MGO. & {$[79]$} \\
\hline & (45) quercetin & $\begin{array}{l}\text { Inhibit AGEs formation via chelating metal ions, trapping MGO, and } \\
\text { trapping ROS. The activity was more potent than aminoguanidine. }\end{array}$ & {$[80,81]$} \\
\hline & (46) hyperoside & Inhibiting AGEs-induced upregulation of RAGE. & {$[153]$} \\
\hline & (47) rutin & $\begin{array}{l}\text { Metal chelating properties. Inhibiting pentosidine formation in collagen/ } \\
\text { glucose model. }\end{array}$ & {$[154]$} \\
\hline & (48) myricetin & $\begin{array}{l}\text { Decreasing insulin resistance. Demonstrates anti-inflammation, anti- } \\
\text { oxidative stress, anti-aldose reductase, anti-nonenzymatic glycation, } \\
\text { and anti-hyperlipidemic activity. }\end{array}$ & {$[155]$} \\
\hline Anthocyanins & (49) cyanidin 3-O-Glc & $\begin{array}{l}\text { Inhibiting dicarbonyl compounds and reducing fructosamine formation, } \\
\text { affecting the initiation and the intermediate state of protein glycation. } \\
\text { Potent ROS scavenging activity. }\end{array}$ & {$[156]$} \\
\hline PMFs & $\begin{array}{l}\text { (50) 5-O-demethyl } \\
\text { nobiletin }\end{array}$ & $\begin{array}{l}\text { Inhibiting protein glycation in several in vitro models: BSA/glucose experi- } \\
\text { ment, fructosamine adduct, and } \alpha \text {-dicarbonyl compounds formation. }\end{array}$ & {$[82]$} \\
\hline Biflavonoids & (51) amentoflavone & $\begin{array}{l}\text { Inhibiting protein glycation in an in vitro assay using fluorescent } \\
\text { measurement. }\end{array}$ & [83] \\
\hline $\begin{array}{l}\text { Naphthoqui- } \\
\text { nones }\end{array}$ & (52) juglone & $\begin{array}{l}\text { Inhibiting prolyl-isomerase-1 (regulating the protein function through } \\
\text { post phosphorylation), which acts against vascular oxidative stress, } \\
\text { endothelial dysfunction, and inflammation. }\end{array}$ & {$[157]$} \\
\hline Anthraquinones & (53) emodin & $\begin{array}{l}\text { Inhibiting fructose-, MGO-, and glyoxal-induced HAS. The antiglycation } \\
\text { effect is due to the binding capacity and stabilization of the HAS protein } \\
\text { structure. }\end{array}$ & [158] \\
\hline Tannins & geraniin & $\begin{array}{l}\text { Inhibiting } \alpha \text {-glucosidase and } \alpha \text {-amylase, which leads to decreased } \\
\text { postprandial hyperglycemia. Anti-AGEs activity through inhibiting the } \\
\text { aldose reductase in vitro. }\end{array}$ & {$[84]$} \\
\hline \multirow[t]{6}{*}{ Terpenes } & (54) thymol & $\begin{array}{l}\text { Inhibiting AGEs formation in a BSA/MGO model by trapping dicarbonyl } \\
\text { intermediates and free radicals. }\end{array}$ & [159] \\
\hline & $\begin{array}{l}\text { 3-O-[ } \alpha \text {-L-arabinofuranosyl- } \\
(1-4)-\beta \text {-D-glucuronopyra- } \\
\text { nosyl]-oleanolic acid }\end{array}$ & $\begin{array}{l}\text { Inhibiting protein glycation in several in vitro models: BSA/glucose experi- } \\
\text { ment, Gk-peptide ribose, and hemoglobin- } \delta \text {-gluconolactone assay. }\end{array}$ & {$[85]$} \\
\hline & astragaloside V & $\begin{array}{l}\text { Inhibiting the CML and pentosidine formation in an in vitro BSA/ribose } \\
\text { model. A promising candidate for preventing diabetic complications. }\end{array}$ & [112] \\
\hline & ginsenoside Rb1 & $\begin{array}{l}\text { Improving insulin resistance, having anti-obesity, anti-hyperglycemic, } \\
\text { and anti-diabetic effect by inhibiting protein glycation, the aldose reduc- } \\
\text { tase activity. }\end{array}$ & {$[160]$} \\
\hline & (55) oleanolic acid & $\begin{array}{l}\text { Inhibiting fructosamine and } \alpha \text {-dicarbonyl compounds formation due to } \\
\text { potent antioxidant activity and trapping MGO. Binding to lysine and argi- } \\
\text { nine residues of the BSA prevents the attachment of the BSA to sugars. }\end{array}$ & {$[161]$} \\
\hline & (56) ursolic acid & $\begin{array}{l}\text { Inhibiting AGEs formation by attenuating the aldose reductase and sorbitol } \\
\text { dehydrogenase activity-the } 2 \text { major enzymes in the polyol pathway. }\end{array}$ & [162] \\
\hline Alkaloids & (57) berberine & $\begin{array}{l}\text { Preventing microvascular complications in diabetes due to protective } \\
\text { effect on high glucose-induced endothelial dysfunction in vitro with } \\
\text { increased NO and endothelium-dependent vasodilatation. }\end{array}$ & {$[163]$} \\
\hline
\end{tabular}


tion of CML by $64.9 \%$ and $53.9 \%$ in the BSA/GO assay; and CEL by $28.9 \%$ and $24.3 \%$ in BSA/MGO assay, respectively [61].

Camellia sinensis L. (Theaceae), which is a rich source of (-)-epigallocatechin 3-O-gallate (EGCG) and (-)-epicatechin 3-O-gallate (ECG), has strong antioxidant properties and inhibits the accumulation of CML and CEL and the activation of RAGE [26]. In the glucose-glycated BSA models, the addition of green tea extract reduced the fluorescence intensity by $64.6 \%$ (while $72.8 \%$ for aminoguanidine). Also, the green tea extract was proven to inhibit $\alpha$ glucosidase and $\alpha$-amylase, resulting in delayed postprandial hyperglycemia [62].

The exocarp $80 \%$ aqueous methanol extracts from Citrus reticulata Blanco $\times$ Citrus sinensis L. (Rutaceae) and Citrus reticulata $\times$ Citrus paradisis Macfad. decreased AGEs formation by lowering the levels of carbonyl compounds in adipocyte cells in vitro [54].

A standardized extract from Ginkgo biloba L. (Ginkgoaceae) (EGb 761) containing 24\% flavonoids and 6\% terpenoids was proven to inhibit the RAGE activation in microvascular endothelial cells induced by hypoxic and hypoglycemic conditions [26].

The fruit of Garcinia mangostana L. (Clusiaceae) (mangosteen) contains catechins, procyanidins, anthocyanin, and xanthones, such as $\alpha$-mangostin. A study investigating the effect of mangosteen pericarp extract on the elasticity of the skin suggested that the water-soluble polyphenols in the water extract from mangosteen inhibit oxidation, resulting in the inhibition of the pentosidine formation in vivo and in vitro [63]. Oral administration of water extract of mangosteen at $100 \mathrm{mg} /$ day to volunteer patients for 3 months reduced the serum pentosidine content and the skin autofluorescence intensity, improving the total skin condition.

The methanolic extract of the leaves of Origanum majorana L. (Lamiaceae) showed inhibition of AGEs formation in vitro and in streptozotocin-induced diabetic rats [64]. Besides the antioxidant activity of the extract, the in vitro studies demonstrated inhibition of protein glycation $\left(\mathrm{IC}_{50}=0.310 \pm 0.054 \mathrm{mg} / \mathrm{ml}\right.$ in the $\mathrm{BSA} / \mathrm{glu}$ cose assay) and trapping abilities against RCS such as methylglyoxal $\left(I_{50}=0.190 \pm 0.028 \mathrm{mg} / \mathrm{ml}\right)$. Treatment of streptozotocindiabetic mice with the Origanum majorana extract and glibenclamide (as a positive control) for 28 days showed beneficial effects on renal metabolic disorders including glucose levels and AGEs formation as compared to the diabetic control and the positive control.

The methanol extract of Thymus vulgaris L. (Lamiaceae) containing the flavonoids (45) quercetin, eriodictyol, 5,6,4'-trihydroxy-7,8,3'-trimethoxyflavone, and cirsilineol suppressed the levels of AGEs formation measured through a fluorescent assay (82\% AGEs inhibition at $1 \mathrm{mg} / \mathrm{ml}$ methanolic extract) [65].

Aralia taibaiensis L. (Araliaceae) showed particularly potent inhibition of the late glycation and the formation of AGEs. The antiglycation properties were addressed to the triterpenoid saponin content in the $n$-butanol extract [66]. The results from testing $1 \mathrm{mg} / \mathrm{ml}$ of the extract showed $77.44 \%$ inhibition in the hemoglobin- $\delta /$ glucose assay (while the value for the $50 \mathrm{mM}$ aminoguanidine was $20.17 \%$ ); $77.63 \%$ in the BSA/glucose assay (while the value for the $50 \mathrm{mM}$ aminoguanidine was $76.52 \%$ ); and $68.19 \%$ in the Gk-peptide/ribose assay (while the value for the $50 \mathrm{mM}$ aminoguanidine was $65.11 \%$ ). The mechanism of action of the plant extract could be explained by scavenging free radicals, reducing oxidative damage, enhancing insulin sensitivity, and regulating the enzymes related to glucose metabolism.

The widely consumed aromatic food spice cumin (Cuminum cyminum L., Apiaceae) showed antiglycation properties in the BSA/fructose intrinsic fluorescence assay. The seeds' flavor constituents, such as sesquiterpenoids, monoterpenoids, and chalcone derivatives, demonstrated a potent role in this biological effect in the in vitro assay (AGEs inhibition $>50 \%$ vs. $35 \%$, respectively, and for aminoguanidine as a positive control) [67].

\section{Isolated natural compounds}

In this review, the selection of the enlisted and discussed pure compounds from medicinal plants ( $\bullet$ Fig. $\mathbf{6}$ ) is according to the established classification of plant secondary metabolites.

Resveratrol (18), a natural antioxidant found in grapes, has been described to inhibit AGEs-induced proliferation and collagen synthesis in vascular smooth muscle [68].

Additionally to its antioxidant and anti-inflammatory properties, (19) curcumin was reported to be a potent inhibitor of AGEs formation and cross-linking of collagen in diabetic rats [69]. It prevented the accumulation of AGE-collagen in diabetic animals; also, Hu et al. reported trapping of MGO by curcumin in cell-free systems and human umbilical vein endothelial cells (HUVECs). Thus, curcumin may prevent MGO-induced endothelial dysfunction by directly trapping MGO $[26,70]$. Another study found that additional mechanisms in how curcumin abolished AGEs-induced effects were through modulating the RAGE expression and interfering with the NF- $K B$ pathway. In conclusion, curcumin is a potential protective agent against AGEs formation and AGEs-induced disruption through several mechanisms of action [71].

Phenolic acids are among the most widely distributed plant nonflavonoid phenolic compounds that can exert antioxidant activity by scavenging hydroxyl radicals and acting as chain-breaking and reducing agents [72]. They can be divided into 2 main types: benzoic acid and cinnamic acid derivatives. Examples of cinnamic acid derivatives are caffeic acid, chlorogenic acid, (28) ferulic acid, and rosmarinic acid, while the benzoic acid derivatives include compounds derived from gallic acid.

Rosmarinic acid (21) and (22) carnosic acid are 2 commercially available active constituents of rosemary extract that can possess anti-AGEs properties in in vitro models: BSA/glucose, BSA/glyoxal, and BSA/methylglyoxal assay [61]. In the BSA/glucose assay, $400 \mu \mathrm{g} / \mathrm{ml}$ rosmarinic acid reduced AGEs formation by $97.4 \%$, while with $50 \mu \mathrm{g} / \mathrm{ml}$ carnosic acid, the inhibition rate was 3 times higher. Rosmarinic acid decreased the MGO formation when added at concentrations higher than $25 \mu \mathrm{g} / \mathrm{ml}$ and did not show an effect on GO concentration at the levels lower than $50 \mu \mathrm{g} / \mathrm{ml}$.

A gallic acid derivative, (23) 7-O-galloyl-D-sedoheptulose, isolated from Cornus officinalis L. (Cornaceae), significantly reduced the expression of RAGE in type $2 \mathrm{db} / \mathrm{db}$ mice $(20$ or $100 \mathrm{mg} / \mathrm{kg}$ body weight/day, per os, administered every day for 6 weeks) and decreased the fluorescent AGEs and ROS in the liver, as well as the expression of oxidative stress- and inflammation-related proteins [73].

Silymarin (29), a flavonolignan obtained from Silybum marianum L. (Asteraceae), has shown, in addition to its free-radical 


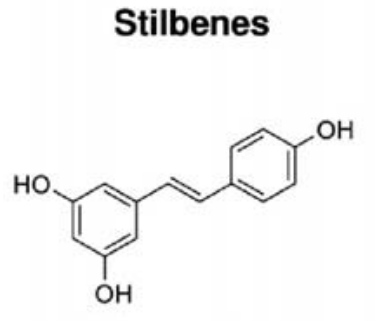

(18) resveratrol

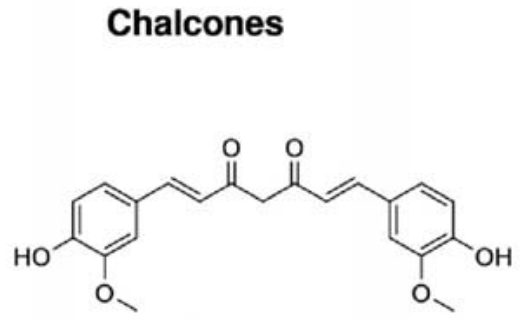

(19) curcumin<smiles>O=C(CCc1ccc(O)cc1)c1c(O)cc(O)cc1OC1OC(CO)C(O)C(O)C1O</smiles>

(20) phlorizin

\section{Phenolic acids}<smiles>O=C(/C=C/c1ccc(O)c(O)c1)CC(Cc1ccc(O)c(O)c1)C(=O)O</smiles>

(21) rosmarinic acid

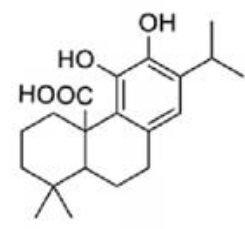

(22) carnosic acid<smiles>O=C(OCC(O)C(O)C(O)C(O)C(=O)CO)c1cc(O)c(O)c(O)c1</smiles>

(23) 7-O-galloyl-D-sedoheptulose<smiles>O=C(O)/C=C/c1ccc(O)c(O)c1</smiles>

(24) caffeic acid<smiles>O=c1oc2c(O)c(O)cc3c(=O)oc4c(O)c(O)cc1c4c23</smiles>

(25) ellagic acid<smiles>COc1cc(C(=O)O)ccc1O</smiles>

(26) vanillic acid<smiles>O=C(/C=C/c1ccc(O)c(O)c1)OC1CC(O)(C(=O)O)CC(O)C1O</smiles>

(27) chlorogenic acid<smiles>COc1cc(/C=C/C(=O)O)ccc1O</smiles>

(28) ferulic acid<smiles>COc1cc(C2Oc3ccc(C4Oc5cc(O)cc(O)c5C(=O)C4O)cc3OC2CO)ccc1O</smiles>

(29) silymarin<smiles>COC(=O)OC1=CC(=O)OC(/C=C/c2ccccc2)C1</smiles>

(30) kawain

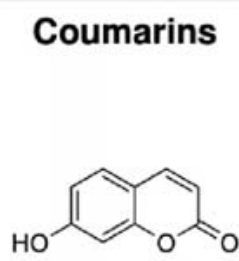

(31) umbelliferone

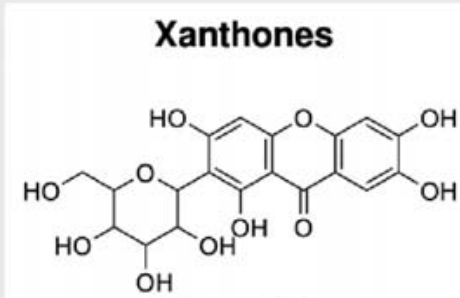

(32) mangiferin<smiles>CCCCOCCOS(=O)(=O)c1ccccc1</smiles>

(33) (+)-catechin<smiles>Oc1cc(O)c2c(c1)O[C@H](c1ccc(O)c(O)c1)[C@H](O)C2</smiles>

(34) (-)-epicetechin<smiles>O=C(O[C@H]1Cc2c(O)cc(O)cc2O[C@@H]1c1ccc(O)c(O)c1)c1cc(O)c(O)c(O)c1</smiles>

(35) (-)-epicatechin gallate<smiles>O=C(O[C@H]1Cc2c(O)cc(O)cc2O[C@@H]1c1cc(O)c(O)c(O)c1)c1cc(O)c(O)c(O)c1</smiles>

(36) epigallocatechin-3-gallate

\section{Flavones}<smiles>O=c1cc(-c2ccc(O)c(O)c2)oc2cc(O)cc(O)c12</smiles>

a<smiles>C/C=C(/C)CC</smiles>

(37) luteolin<smiles>Cc1cc(=O)c2c(O)cccc2o1</smiles>

(38) apigen in<smiles>CC1OC(OCC2OC(Oc3cc(O)c4c(c3)OCCC4=O)C(O)C(O)C2O)C(O)C(O)C1O</smiles>

(39) diosmin<smiles>CCCc1ccc(OC)c(O)c1</smiles>

(40) vitexin

Fig. 6 Chemical structures of natural products with AGEs inhibiting properties presented based on the classification of plant secondary metabolites. 


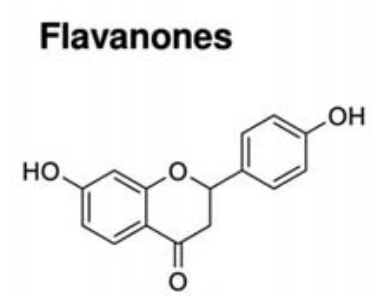

(41) naringenin<smiles>O=C1CC(c2cc(O)c(O)c(OC3Oc4cc(O)cc(O)c4O3)c2)OC(CO)C1O</smiles>

(42) plantagoside<smiles>O=C1CC(c2ccc(OC3OC(CO)C(O)C(O)C3O)cc2)Oc2cc(O)ccc21</smiles>

(43) liquiritin

\section{Flavonols}<smiles>O=c1c(O)c(-c2ccc(O)cc2)oc2cc(O)cc(O)c12</smiles>

(44) kaempferol<smiles>O=c1c(O)c(-c2ccc(O)c(O)c2)oc2cc(O)cc(O)c12</smiles>

(45) quercetin<smiles>O=c1c(OC2OC(CO)C(O)C(O)C2O)c(-c2ccc(O)c(O)c2)oc2cc(O)cc(O)c12</smiles>

(46) hyperoside<smiles>CC1OC(OCC2OC(Oc3c(-c4ccc(O)c(O)c4)oc4cc(O)cc(O)c4c3=O)C(O)C(O)C2O)C(O)C(O)C1O</smiles>

(47) rutin

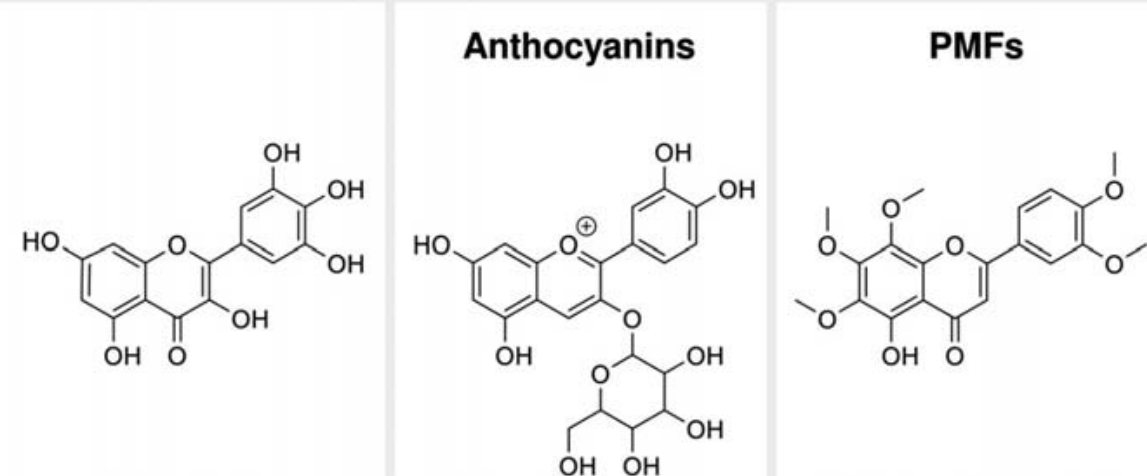

(48) myricetin

(49) cyanidin-3-0-Glu

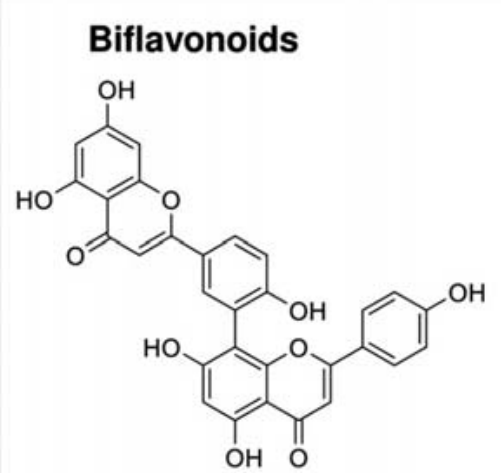

(51) amentoflavone

\section{Naphthoquinones Anthraquinones Terpenes}<smiles>CC1C=CC(=O)c2c(O)cccc21</smiles>

(52) juglone<smiles>Cc1cc(O)c2c(c1)C(=O)c1cc(O)cc(O)c1C2=O</smiles>

(53) emodin<smiles>Cc1ccc(C(C)C)c(O)c1</smiles>

(54) thymol<smiles>CC1(C)CCC2(C(=O)O)CCC3(C)C(=CCC4C5CCC(O)C(C)(C)C5CCC43C)C2C1</smiles>

(55) oleanoic acid<smiles>CC1CCC2(C(=O)O)CCC3(C)C(=CCC4C5CCC6C(C)(C)C(O)CCC6(C)C5CCC43C)C2C1C</smiles>

(56) ursolic acid

\section{Terpenes}<smiles>Cc1ccc(C(C)C)c(O)c1</smiles>

b (54) thymol<smiles>CC1(C)CCC2(C(=O)O)CCC3(C)C(=CCC4C5(C)CCC(O)C(C)(C)C5CCC43C)C2C1</smiles>

(55) oleanoic acid<smiles>CC1CCC2(C(=O)O)CCC3(C)C(=CCC4C5CCC6C(C)(C)C(O)CCC6(C)C5CCC43C)C2C1C</smiles>

(56) ursolic acid
Alkaloids<smiles>COc1ccc2cc3[n+](cc2c1OC)CCc1cc2c(cc1-3)OCO2</smiles>

(57) berberine

- Fig. 6 Continued 
scavenging properties, in vitro inhibitory effects on the late-stage glycation and subsequent cross-linking [26].

Kavalactones, (30) DL-kawain and methysticine, are a class of lactone compounds isolated from Alpinia zerumbet Pers. (Zingiberaceae) and used in the preparation of traditional food in the Okinawan islands. They are thought to contribute to the longevity of the people in this region [74]. The prevention of AGEs formation was investigated by the BSA/glucose assay where both kawain $\left(I C_{50}=43.5 \pm 1.2 \mu \mathrm{M}\right)$ and methysticine $\left(I_{50}=45.0 \pm 1.3 \mu \mathrm{M}\right)$ inhibited the process significantly better than aminoguanidine $\left(\mathrm{IC}_{50}=231.0 \pm 11.5 \mu \mathrm{M}\right)$.

Mangiferin (32)-a major xanthone glucoside in the roots of Anemarrhena asphodeloides Bunge (Asparagaceae) traditionally used in Chinese medicine-has been reported for its antidiabetic and anti-inflammatory effects in a diabetic cardiomyopathy rat model. Mangiferin reduced AGEs production and expression of RAGE, preventing the release of inflammatory cytokines and inhibiting the accumulation of ROS [75].

Flavonoids have been extensively investigated as AGEs inhibitors. In general, it is difficult to draw a clear line between the structural characteristics of flavonoids for inhibition of protein glycation and radical scavenging activities. However, Matsuda et al. suggested the following statements can be made about potential AGEs inhibitors: (1) an increasing number of hydroxyl groups in position 3', 4', 5, 7 is associated with increased inhibitory activity; (2) flavones are more active than the corresponding flavonols, flavanones, and isoflavones; (3) methylation or glycosylation of the 4'-hydroxyl group of flavones, flavonols, and flavanones reduces activity; (4) methylation or glycosylation of the 3-hydroxyl group of flavonols tends to increase activity; (5) glycosylation of the 7-hydroxyl group of flavones and isoflavones reduces activity [76]. During the past few decades, a vast number of flavonoids have been reported to possess promising antiglycation activity.

Significant inhibition of AGEs formation by (33) (+)-catechin-a major metabolite of lotus seedpod oligomeric procyanidins-was demonstrated in a study by Wu et al. The anti-glycation properties of the compound were related to its potent activity of trapping dicarbonyl intermediates $\left(\mathrm{IC}_{50}\right.$ value $0.049 \pm 0.019 \mathrm{mg} / \mathrm{ml}$; scavenging MGO activity $78.25 \pm 2.99 \%$ ) and its antioxidant capacities [77].

Plantagoside (42) (5,7,4',5'-tetrahydroxyflavone-3'-O-glucoside) and its aglycone (5,7,3',4',5'-pentahydroxyflavone) obtained from the $50 \%$ ethanolic extract of Plantago major L. (Plantaginaceae) seeds were proven to inhibit both the formation of AGEs in physiological conditions and protein cross-linking glycation. The fluorometric BSA assay reported $\mathrm{IC}_{50} 1.2 \mu \mathrm{M}$ for plantagoside and $\mathrm{IC}_{50} 18.0 \mu \mathrm{M}$ for the aglycone, which was 83- and 5.5-times stronger, respectively, than the one with aminoguanidine $\left(\mathrm{IC}_{50}\right.$ $100.0 \mu \mathrm{M}$ ) used as a positive control [78]. Additionally, $18.0 \mu \mathrm{M}$ plantagoside was identified to inhibit AGEs formation at the physiological level.

Kaempferol (44), the well-known antioxidant flavonol aglycone, was detected to inhibit the early stages of AGEs formation by scavenging $\mathrm{MGO}$ in physiological conditions, forming monoMGO and di-MGO adducts. The data showed that MGO was trapped up to $60 \%$ by $0.25 \mathrm{mM}$ aminoguanidine (although the inhibitory activity was not dose-dependent), in contrast to the same concentration of kaempferol, where the remaining MGO decreased significantly to $32 \%$ in a dose-dependent manner [79].

Quercetin (45) is another example of a flavonol aglycone that was proven to inhibit MGO-mediated AGEs formation as well as glucose- and ribose-mediated AGEs formation [80]. One hundred $\mu \mathrm{M}$ exhibited $50 \%$ inhibition of MGO, which was the highest result among other polyphenols tested in the assay such as (-)-epicatechin, gallic acid, hesperetin, (47) rutin, and kaempferol. Another study compared the antiglycation properties of quercetin and aminoguanidine, the generally used positive control in various fluorescent assays: hemoglobin- $\delta$-gluconolactone ( $\delta$-Glu) assay, MGO/HSA (human serum albumin), GO/HSA, and Gk-peptide ( $N$ acetyl-glycyl-lysine methyl ester)/ribose tests [81]. In the $\mathrm{GO} /$ $\mathrm{HSA}, 500 \mu \mathrm{M}$ quercetin inhibited almost $75 \%$ of the post-Amadori glycation, while $10 \mathrm{mM}$ of aminoguanidine reached $72.5 \%$ inhibition. In the Gk-peptide/ribose assay, which is used to evaluate the inhibiting properties of the compound against cross-linking, 200 and $500 \mu \mathrm{M}$ quercetin inhibited $61.5 \%$ and $69.6 \%$ of the late glycation products over 14 days. As for aminoguanidine, the $62 \%$ inhibition in the same test was achieved in a concentration of $10 \mathrm{mM}$.

In an in vitro screening assay, (47) rutin exhibited a significant inhibitory effect at the intermediate stage of AGEs formation by trapping $\mathrm{MGO}$ with an $\mathrm{IC}_{50}$ value of $71.8 \mu \mathrm{M}$ [26].

PMFs, particularly (50) 5-O-demethyl nobiletin isolated from the chloroform fraction of Citrus depressa Hayata (Rutaceae) peel, had significantly higher AGEs inhibitory activity $\left(\mathrm{IC}_{50}=64.2 \pm\right.$ $3.6 \mu \mathrm{M})$ than aminoguanidine $\left(\mathrm{IC}_{50}=484.3 \pm 7.3 \mu \mathrm{M}\right)$ measured in vitro through fluorimetric methods [82].

Amentoflavone (51), a biflavonoid isolated from the methanol leaves extract of Calophyllum flavoramulum Hend. \&Wyatt-Sm. (Calophyllaceae), was found to possess potent anti-AGEs activity in vitro: $I_{50}=0.05 \mathrm{mM}$, while the activity of quercetin, used as a reference compound, was moderately strong: $\mathrm{IC}_{50}=0.5 \mathrm{mM}$ [83]. Amentoflavone can exert its anti-AGEs activity through various mechanisms like radical scavenging and chelation of divalent metal ions as well as trapping dicarbonyl species.

Geraniin, the main ellagitannin in the crude extract from Nephelium lappaceum L. (Sapindaceae) peels, is an effective inhibitor of the carbohydrate enzymes $\alpha$-glucosidase and $\alpha$-amylase; therefore, it has the potential to interrupt carbohydrate digestion and the absorption of glucose, resulting in suppressed postprandial hyperglycemia. Additionally, in vitro studies proved its significant aldose reductase-inhibiting properties, consequently, decreasing the formation of AGEs [84]. It has been demonstrated that geraniin has antioxidant, immune-modulation, antimicrobial, and anticancer properties besides the promising therapeutic effects on hypertension, cardiovascular diseases, and metabolic dysregulation.

Twelve triterpenoid saponins isolated from the extract of root bark of Aralia taibaiensis Z.Z. Wang \& H. C. Zheng (Araliaceae), a plant frequently used for the treatment of diabetes mellitus in traditional Chinese medicine, exhibited both antioxidant and antiglycation properties. The activity against AGEs formation was detected through the hemoglobin- $\delta$-gluconolactone assay, BSA/glucose assay, and Gk-peptide/ribose assay, and it was significantly higher for the 3-O-[ $\alpha$-L-arabinofuranosyl-(1-4)- $\beta$-D-glucurono- 
pyranosyl]-oleanolic acid (TA24); 3-O-\{ $\beta$-D-glucopyranosyl-(1-2)[ $\beta$-D-glucopyranosyl-(1-3)]- $\beta$-D-glucuronopyranosyl\}-oleanolic acid (TA21), and 3-O-\{ $\beta$-D- glucopyranosyl-(1-2)-[ $\beta$-D-glucopyranosyl-(1-3)]- $\beta$-D-glucuronopyranosyl\}-oleanolic acid 28-O- $\beta$-Dglucopyranosyl ester (TA9) [85].

Astragaloside $V$ from the crude extract of Astragali Radix has shown inhibition of the formation of CML and pentosidine in in vitro samples [26, 50,86].

Other groups of compounds include anthraquinones, such as (53) emodine, and carotenoids, especially lutein and $\beta$-carotene from the ethyl acetate fraction of the green microalgae Chlorella zofingiensis Donz. (Oocystaceae), that contribute to the strong antiglycation activity of this species; unsaturated fatty acids such as linoleic acid, arachidonic acid, and eicosapentaenoic acid from Nitzschia laevis Hassall (Bacillariaceae) were reported as inhibitors of glycation. Moreover, (56) ursolic acid was suggested to play a significant role in patients with diabetes in reducing hyperglycemia, hepatic glucose production, hyperlipidemia, and the influx of glucose through the polyol pathway.

Considering that AGEs are major pathogenic propagators in many human diseases, and especially in diabetes and its complications, it is of great importance to identify anti-glycation substances and to examine their mode of action. It is important to note that one AGE inhibitor will not act on all pathways; therefore, it is difficult to accept the existence of a magic bullet. Nevertheless, the current review seeks to address the lacuna in contemporary research for new potential drugs or lead compounds with AGEs inhibiting properties. However, despite the tremendous efforts of many scientists in the field, none of the discussed natural products or extracts have progressed to clinical trials or even systematic preclinical studies. The reason for this can be found in the current lack of validated analytical methods for the unambiguous determination of AGEs inhibiting properties of particular candidates. Future work involving advanced analytical techniques and suitable sample preparation steps is expected to reveal the positive hits among plant compounds as inhibitors of AGEs formation.

\section{Conclusion}

Pathophysiological accumulation of AGEs in vivo has been associated with the progression of many health disorders. The current review aimed to summarize the reports from the last 3 decades for plant-derived natural products with antiglycation activity. A vast number of plant extracts and pure compounds exhibit their AGEs inhibitory activity through several mechanisms of action, for example, trapping dicarbonyl intermediates, hyperglycemic activity, decreased expression of RAGE, and potent free radical scavenging activity. Additionally, some of them possess other pharmacological properties such as anti-inflammatory and the reduction of insulin resistance, which can contribute to improving the overall glycemic control and endothelial function. In general, the promising antiglycation activity of the extracts strongly correlates with their total phenolic content. However, many nonphenolic compounds such as terpenoids, flavonoids, and alkaloids demonstrated a high potential to reduce the nonenzymatic glycosylation.
The plant-derived AGEs inhibitors represent attractive novel therapeutic agents that can join forces with the already existing synthetic drugs in the treatment and/or prevention of health issues with major importance like diabetes, neurodegenerative disorders, and aging. Contrary to synthetic agents, the full potential of plant products has still not been revealed and requires further comprehensive analysis to expand our knowledge of antiglycation phytomolecules. However, a crucial aspect to identifying the potent and promising AGEs inhibitors from natural origin is the use of validated analytical methods for precise determination of their AGEs-inhibiting properties. Consequently, this can determine the outcome for developing medications using plant products, conducting clinical trials, and eventually, having new therapeutic agents reaching the market.

\section{Contributors' Statement}

Data collection: S. Velichkova; analysis and interpretation of the data: S. Velichkova, L. Pieters, K. Foubert; drafting the manuscript: S. Velichkova, L. Pieters; critical revision of the manuscript: S. Velichkova, L. Pieters, K. Foubert.

\section{Acknowledgements}

This work was supported by the Fund for Scientific Research of Flanders (FWO, grand number: 11T8118N).

\section{Conflict of Interest}

The authors declare that they have no conflict of interest.

\section{References}

[1] Dregan A, Charlton J, Chowienczyk P, Gulliford M. Chronic inflammatory disorders and risk of type 2 diabetes mellitus, coronary heart disease, and stroke: a population-based cohort study. Circulation 2014; 130 : 837-844

[2] van der Leeuw J, Beulens J, van Dieren S, Schalkwijk C, Glatz J, Hofker M, Verschuren M, Boer J, van der Graaf Y, Visseren F, Peelen L, van der Schouw Y. Novel biomarkers to improve the prediction of cardiovascular event risk in type 2 diabetes mellitus. J Am Heart Assoc 2016; 5: 1-11

[3] Thornalley P. The clinical significance of glycation. Clin Lab 1999; 45: 263-273

[4] Fishman S, Sonmez H, Basman C, Singh V, Poretsky L. The role of advanced glycation end-products in the development of coronary artery disease in patients with and without diabetes mellitus: a review. Mol Med 2018; 24: 1-12

[5] Goh SY, Cooper M. The role of advanced glycation end products in progression and complications of diabetes. J Clin Endocrinol Metab 2008; 93: 1143-1152

[6] Rabbani N, Thornalley P. Glycation research in amino acids: a place to call home. Amino Acids 2012; 42: 1087-1096

[7] Scheijen J, van de Waarenburg M, Stehouwer C, Schalkwijk C. Measurement of pentosidine in human plasma protein by a single-column highperformance liquid chromatography method with fluorescence detection. J Chromatogr B Anal Technol Biomed Life Sci 2009; 877: 610-614

[8] Stitt A. Advanced glycation: an important pathological event in diabetic and age related ocular disease. Br J Ophthalmol 2001; 85: 746-753

[9] Nedić O, Rattan S, Grune T, Trougakos I. Molecular effects of advanced glycation end products on cell signalling pathways, ageing and pathophysiology. Free Radic Res 2013; 47: 28-38 
[10] Iannuzzi C, Irace G, Sirangelo I, Williams T. Differential effects of glycation on protein aggregation and amyloid formation. Mol Biosci 2014; 1 : $1-8$

[11] Niwa T. Dicarbonyls (Glyoxal, Methylglyoxal, and 3-Deoxyglucosone). In: Nibbering D, Desiderio N, eds. Uremic Toxins. Hoboken: Wiley; 2012: 177-192

[12] Machiels D, Istasse L. La réaction de Maillard: importance et applications en chimie des aliments. Ann Med Vet 2002; 146: 347-352

[13] Thornalley P, Langborg A, Minhas H. Formation of glyoxal, methylglyoxal and 3-deoxyglucosone in the glycation of proteins by glucose. Biochem J 2015; 344: 109-116

[14] Yaylayan V, Huyqhues-Despointes A. Chemistry of Amadori rearrangement products: analysis, synthesis, kinetics, reactions, and spectroscopic properties. Crit Rev Food Sci Nutr 1994; 34: 321-369

[15] Namiki M, Hayashu T. New mechanism of the Maillard reaction free radical involving sugar fragmentation and formation. Mail React Foods Nutr 1983; 26: 21-46

[16] Wolff S, Dean R. Glucose autoxidation and protein modification. The potential role of 'autoxidative glycosylation' in diabetes. Biochem J 1987; 245: $243-250$

[17] Wolff S, Jiang Z, Hunt J. Protein glycation and oxidative stress in diabetes mellitus and ageing. Free Radic Biol Med 1991; 10: 339-352

[18] Ahmed N. Advanced glycation endproducts-role in pathology of diabetic complications. Diabetes Res Clin Pract 2005; 67: 3-21

[19] Miura J, Yamagishi S, Uchigata Y, Takeuchi M, Yamamoto H, Makita Z, Iwamoto Y. Serum levels of non-carboxymethyllysine advanced glycation endproducts are correlated to severity of microvascular complications in patients with Type 1 diabetes. J Diabetes Complications 2003; 17: $16-21$

[20] Gkogkolou P, Böhm M. Advanced glycation end products: key players in skin aging? Dermatoendocrinol 2012; 4: 259-270

[21] Frye E, Degenhardt T, Thorpe S, Baynes J. Role of the Maillard reaction in aging of tissue proteins: advanced glycation end product-dependent increase in imidazolium cross-links in human lens proteins. J Biol Chem 1998; 273: 18714-18719

[22] Sell D, Monnier V. End-stage renal disease and diabetes catalyze the formation of a pentose-derived crosslink from aging human collagen. J Clin Invest 1990; 85: 380-384

[23] Wautier M, Massin P, Guillausseau P, Huijberts M, Levy B, Boulanger E, Laloi-Michelin M, Wautiere J. N-(carboxymethyl)-lysine as a biomarker for microvascular complications in type 2 diabetic patients. Diabetes Metab 2003; 29: 44-52

[24] Wells-Knecht K, Brinkmann E, Wells-Knecht M, Litchfield J, Ahmed M, Reddy S, Zyzak D, Thorpe S, Baynes J. New biomarkers of Maillard reaction damage to proteins. Nephrol Dial Transplant 1996; 11: 41-47

[25] Fournet $M$, Bonté $F$, Desmoulière $A$. Glycation damage: a possible hub for major pathophysiological disorders and aging. Aging Dis 2018; 9: $880-900$

[26] Wu C, Huang S, Lin J, Yen G. Inhibition of advanced glycation endproduct formation by foodstuffs. Food Funct 2011; 2: 224-234

[27] Dyer D, Dunn J, Thorpe S, Bailie K, Lyons T, Mccance D, Baynes ]. Accumulation of Maillard reaction products in skin collagen in diabetes and aging. J Clin Invest 1993; 91: 2463-2469

[28] Engelen L, Stehouwer C, Schalkwijk C. Current therapeutic interventions in the glycation pathway: evidence from clinical studies. Diabetes. Obes Metab 2013; 15: 677-689

[29] Moldogazieva N, Mokhosoev I, Mel'Nikova T, Porozov Y, Terentiev A. Oxidative stress and advanced lipoxidation and glycation endproducts (ALEs and AGEs) in aging and age-related diseases. Oxid Med Cell Longev 2019; 2019: 1-14
[30] Lyons T, Jenkins A. Glycation, oxidation, and lipoxidation in the development of the complications of diabetes: a carbonyl stress hypothesis. Diabetes Rev 1997; 5: 365-391

[31] Ramasamy R, Vannucci S, Yan S, Herold K, Yan S, Schmidt A. Advanced glycation end products and RAGE: a common thread in aging, diabetes, neurodegeneration, and inflammation. Glycobiology 2005; 15: 16-28

[32] Nowotny K, Jung T, Höhn A, Weber D, Grune T. Advanced glycation endproducts and oxidative stress in type 2 diabetes mellitus. Biomolecules 2015; 5: 194-222

[33] Ott C, Jacobs K, Haucke E, Navarrete Santos A, Grune T, Simm A. Role of advanced glycation end products in cellular signaling. Redox Biol 2014; 2: 411-429

[34] Barbezier N, Tessier F, Chango A. Le récepteur des produits de glycation avancée RAGE/AGER: une vue intégrative pour des applications en clinique. Ann Biol Clin (Paris) 2014; 72: 669-680

[35] Younessi P, Yoonessi A. Advanced glycation endproducts and their receptor-mediated roles: inflammation and oxidative stress. Iran J Med Sci 2011; 36: 154-166

[36] Yamagishi S, Nakamura N, Matsui T. Glycation and cardiovascular disease in diabetes: a perspective on the concept of metabolic memory. J Diabetes 2017; 9: 141-148

[37] Cade T. Diabetes-related microvascular and macrovascular diseases in the physical therapy setting. Phys Ther 2008; 88: 1322-1335

[38] Yamagishi S, Nakamura K, Matsui T. Advanced glycation endproducts (AGEs) and their receptor (RAGE) system in diabetic retinopathy. Curr Drug Discov Technol 2006; 3: 83-88

[39] Horiuchi S, Imai N, Ueno M, Kawashima S, Miyakawa Y, Suzuki Y, Nakamaru T, Karasawa R, Araki N, Shimada H, Gejyo F, Arakawa M, Nishi S. Histological localization of advanced glycosylation end products in the progression of diabetic nephropathy. Nephron 2008; 76: 153-160

[40] Babaei-Jadidi R, Karachalias N, Ahmed N, Battah S, Thornalley P. Prevention of incipient diabetic nephropathy by high-dose thiamine and benfotiamine. Diabetes 2003; 52: 2110-2120

[41] Bohlender J, Franke S, Stein G, Wolf G. Advanced glycation end products and the kidney. Am J Physiol - Ren Physiol 2005; 289: 645-659

[42] Ren X, Ren L, Wei Q, Shao H, Chen L, Liu N. Advanced glycation endproducts decreases expression of endothelial nitric oxide synthase through oxidative stress in human coronary artery endothelial cells. Cardiovasc Diabetol 2017; 16: 1-12

[43] Van Putte L, De Schrijver S, Moortgat P. The effects of advanced glycation end products (AGEs) on dermal wound healing and scar formation: a systematic review. Scars Burn Heal 2016; 2: 1-14

[44] Sasaki N, Fukatsu R, Tsuzuki K, Hayashi Y, Yoshida T, Fujii N, Koike T, Wakayama I, Yanagihara R, Garruto R, Amano N, Makita Z. Advanced glycation end products in Alzheimer's disease and other neurodegenerative diseases. Am J Pathol 1998; 153: 1149-1155

[45] Peng X, Ma J, Chen F, Wang M. Naturally occurring inhibitors against the formation of advanced glycation end-products. Food Funct 2011; 2: 289-301

[46] Peyroux J, Sternberg M. Advanced glycation endproducts (AGEs): pharmacological inhibition in diabetes. Pathol Biol 2006; 54: 405-419

[47] $\mathrm{Wu} \mathrm{CH}$, Yen GC. Inhibitory effect of naturally occurring flavonoids on the formation of advanced glycation endproducts. J Agric Food Chem 2005; 53: 3167-3173

[48] Younus H, Anwar S. Prevention of non-enzymatic glycosylation (glycation): implication in the treatment of diabetic complication. Int J Health Sci (Qassim) 2016; 10: 247-263

[49] Poitevin P, Levy B, Wolffenbuttel B, Boulanger C, Egan J, Vasan S, Ulrich P, Swennen G, Huijberts M, Crijns F, Cerami A. Breakers of advanced glycation endproducts restore large artery properties in experimental diabetes. Proc Natl Acad Sci 1998; 95: 4630-4634 
[50] Odjakova M, Popova E, Sharif M, Mironova R. Plant-derived Agents with anti-glycation Activity. In: Petrescu S, ed. Glycosylation. London: Intech Open Science; 2011: 64; 223-256

[51] Booth A, Khalifah R, Hudson B. Thiamine pyrophosphate and pyridoxamine inhibit the formation of antigenic advanced glycation end-products: comparison with aminoguanidine 1. Biochem Biophys Res Commun 1996; 220: 113-119

[52] Reddy VP, Beyaz A. Inhibitors of the Maillard reaction and AGE breakers as therapeutics for multiple diseases. Drug Discov Today 2006; 11: 646654

[53] Thilavech T, Ngamukote S, Abeywardena M, Adisakwattana S. Protective effects of cyanidin-3-rutinoside against monosaccharides-induced protein glycation and oxidation. Int J Biol Macromol 2015; 75: 515-520

[54] Khangholi S, Majid F, Berwary N, Ahmad F, Aziz R. The mechanisms of inhibition of advanced glycation end products formation through polyphenols in hyperglycemic condition. Planta Med 2015; 82: 32-45

[55] Kaewnarin K, Niamsup H, Shank L, Rakariyatham N. Antioxidant and antiglycation activities of some edible and medicinal plants. Chiang Mai J Sci 2014; 41: 105-116

[56] Atanasov A, Waltenberger B, Pferschy-Wenzig E, Linder T, Wawrosch C, Uhrin P, Temml V, Wang L, Schwaiger S, Heiss E, Rollinger J, Schuster D, Breuss J, Bochkov V, Mihovilovic M, Kopp B, Bauer R, Dirsch V, Stuppner $\mathrm{H}$. Discovery and resupply of pharmacologically active plant-derived natural products: a review. Biotechnol Adv 2015; 33: 1582-1614

[57] Tsuji-Naito K, Saeki H, Hamano M. Inhibitory effects of Chrysanthemum species extracts on formation of advanced glycation end products. Food Chem 2009; 116: 854-859

[58] Jang D, Yoo N, Kim N, Lee Y, Kim C, Kim J, Kim J, Kim ]. 3,5-Di-O-caffeoylepi-quinic acid from the leaves and stems of Erigeron annuus inhibits protein glycation, aldose reductase, and cataractogenesis. Biol Pharm Bull 2010; 33: 329-333

[59] Kim H, Kim K. Protein glycation inhibitory and antioxidative activities of some plant extracts in vitro. J Agric Food Chem 2003; 51: 1586-1591

[60] Bains Y, Gugliucci A. Ilex paraguariensis and its main component chlorogenic acid inhibit fructose formation of advanced glycation endproducts with amino acids at conditions compatible with those in the digestive system. Fitoterapia 2017; 117: 6-10

[61] Ou J, Huang J, Wang M, Ou S. Effect of rosmarinic acid and carnosic acid on AGEs formation in vitro. Food Chem 2017; 221: 1057-1061

[62] Ramlagan P, Rondeau P, Planesse C, Neergheen-Bhujun V, Bourdon E, Bahorun T. Comparative suppressing effects of black and green teas on the formation of advanced glycation end products (AGEs) and AGE-induced oxidative stress. Food Funct 2017; 8: 4194-4209

[63] Ohno RI, Moroishi N, Nagai M, Nagai R. Mangosteen pericarp extract inhibits the formation of pentosidine and ameliorates skin elasticity. J Clin Biochem Nutr 2015; 57: 27-32

[64] Perez Gutierrez RM. Inhibition of advanced glycation endproduct formation by Origanum majorana L. in vitro and in streptozotocin-induced diabetic rats. Evid Based Complement Alternat Med 2012; 2012: 1-8

[65] Morimitsu Y, Yoshida K, Hirota A, Esaki S. Protein glycation inhibitors from thyme (Thymus vulgaris). Biosci Biotechnol Biochem 1995; 59: 2018-2021

[66] Xi M, Hai C, Tang H, Chen M, Fang K, Liang X. Antioxidant and antiglycation properties of total saponins extracted from Traditional Chinese Medicine used to treat diabetes mellitus. Phyther Res 2008; 22: 544-549

[67] Zhang Y, Ma H, Liu W, Yuan T, Seeram N. New antiglycative compounds from cumin (Cuminum cyminum) spice. J Agric Food Chem 2015; 63: 10097-10102

[68] Mizutani K, Ikeda K, Yamori Y. Resveratrol inhibits AGEs-induced proliferation and collagen synthesis activity in vascular smooth muscle cells from stroke-prone spontaneously hypertensive rats. Biochem Biophys Res Commun 2000; 274: 61-67
[69] Sajithlal G, Chithra P, Chandrakasan G. Effect of curcumin on the advanced glycation and cross-linking of collagen in diabetic rats. Biochem Pharmacol 1998; 56: 1607-1614

[70] Hu T, Liu C, Chyau C, Hu M. Trapping of methylglyoxal by curcumin in cell-free systems and in human umbilical vein endothelial cells. J Agric Food Chem 2012; 60: 8190-8196

[71] Alizadeh M, Kheirouri S. Curcumin against advanced glycation end products (AGEs) and AGEs-induced detrimental agents. Crit Rev Food Sci Nutr 2019; 59: 1169-1177

[72] Varelis P, Melton L, Shahidi F. Encyclopedia of Food Chemistry. Amsterdam: Elsevier; 2019

[73] Park C, Noh J, Tanaka T, Roh S, Lee J, Yokozawa T. Polyphenol isolated from Corni Fructus, 7-O-galloyl-d-sedoheptulose, modulates advanced glycation endproduct-related pathway in type 2 diabetic $\mathrm{db} / \mathrm{db}$ mice. Arch Pharm Res 2015; 38: 1270-1280

[74] Upadhyay A, Tuenter E, Exarchou V, Apers S, Pieters L. Kavalactones, a novel class of protein glycation and lipid peroxidation inhibitors. Planta Med 2014; 80: 1001-1008

[75] Hou J, Zheng D, Fung G, Deng H, Chen L, Liang J, Jiang Y, Hu Y. Mangiferin suppressed advanced glycation end products (AGEs) through NF-KB deactivation and displayed anti-inflammatory effects in streptozotocin and high fat diet-diabetic cardiomyopathy rats. Can J Physiol Pharmacol 2016; 94: 1-22

[76] Matsuda H, Wang T, Managi H, Yoshikawa M. Structural requirements of flavonoids for inhibition of protein glycation and radical scavenging activities. Bioorganic Med Chem 2003; 11: 5317-5323

[77] Wu Q, Li S, Li X, Fu X, Sui Y, Guo T, Xie B, Sun Z. A significant inhibitory effect on advanced glycation end product formation by catechin as the major metabolite of lotus seedpod oligomeric procyanidins. Nutrients 2014; 6: 3230-3244

[78] Matsuura N, Aradate T, Kurosaka C, Ubukata M, Kittaka S, Nakaminami Y, Gamo K, Kojima H, Ohara M. Potent protein glycation inhibition of plantagoside in Plantago major seeds. BioMed 2014; 2014: 1-5

[79] Yang B, Choi E, Shim S. Inhibitory activities of kaempferol against methylglyoxal formation, intermediate of advanced glycation end products. Appl Biol Chem 2017; 60: 57-62

[80] Bhuiyan M, Mitsuhashi S, Sigetomi K, Ubukata M. Quercetin inhibits advanced glycation end product formation via chelating metal ions, trapping methylglyoxal, and trapping reactive oxygen species. Biosci Biotechnol Biochem 2017; 81: 882-890

[81] Ashraf J, Shahab U, Tabrez S, Lee E, Choi I, Ahmad S. Quercetin as a finer substitute to aminoguanidine in the inhibition of glycation products. Int J Biol Macromol 2015; 77: 188-192

[82] Upadhyay A, Tuenter E, Amin A, Exarchou V, Hermans N, Apers S, Pieters L. 5-O-Demethylnobiletin, a polymethoxylated flavonoid, from Citrus depressa Hayata peel prevents protein glycation. J Funct Foods 2014; 11: 243-249

[83] Ferchichi L, Derbré S, Mahmood K, Touré K, Guilet D, Litaudon M, Awang K, Hadi A, Le Ray AM, Richomme P. Bioguided fractionation and isolation of natural inhibitors of advanced glycation end-products (AGEs) from Calophyllum flavoramulum. Phytochemistry 2012; 78: 98-106

[84] Cheng H, Ton S, Abdul Kadir K. Ellagitannin geraniin: a review of the natural sources, biosynthesis, pharmacokinetics and biological effects. Phytochem Rev 2017; 16: 159-193

[85] Xi M, Hai C, Tang H, Wen A, Chen H, Liu R, Liang X, Chen M. Antioxidant and antiglycation properties of triterpenoid saponins from Aralia taibaiensis traditionally used for treating diabetes mellitus. Redox Rep 2010; $15: 20-28$

[86] Derbré S, Gatto J, Pelleray A, Coulon L, Séraphin D, Richomme P. Automating a 96-well microtiter plate assay for identification of AGEs inhibitors or inducers: application to the screening of a small natural compounds library. Anal Bioanal Chem 2010; 398: 1747-1758 
[87] Tang Y, Hu C, Sang S. Characterization of reaction products and mechanisms between serotonin and methylglyoxal in model reactions and mice. J Agric Food Chem 2020; 68: 2437-2444

[88] Rabbani N, Shaheen F, Anwar A, Masania J, Thornalley P. Assay of methylglyoxal-derived protein and nucleotide AGEs. Biochem Soc Trans 2014; 42: 511-517

[89] Rahbar S, Natarajan R, Yerneni K, Scott S, Gonzales N, Nadler J. Evidence that pioglitazone, metformin and pentoxifylline are inhibitors of glycation. Clin Chim Acta 2000; 301: 65-77

[90] Hanssen N, Engelen L, Ferreira I, Scheijen J, Huijberts M, Van Greevenbroek M, van der Kallen C, Dekker J, Nijpels G, Stehouwer C, Schalkwijk C. Plasma levels of advanced glycation endproducts $\mathrm{N} \varepsilon$-(carboxymethyl) lysine, $N \varepsilon$-(carboxyethyl)lysine, and pentosidine are not independently associated with cardiovascular disease in individuals with or without type 2 diabetes: the Hoorn and CODAM studies. J Clin Endocrinol Metab 2013; 98: 1369-1373

[91] Rahbar S, Figarola J. Inhibitors and breakers of advanced glycation endproducts (AGEs): A review. Curr Med Chem Endocr Metab Agents 2002; 2: 135-161

[92] Monnier V. Intervention against the Maillard reaction in vivo. Arch Biochem Biophys 2003; 419: 1-15

[93] Odani H, Shinzato T, Usami J, Matsumoto Y, Frye E, Baynes J, Maeda K. Imidazolium crosslinks derived from reaction of lysine with glyoxal and methylglyoxal are increased in serum proteins of uremic patients: evidence for increased oxidative stress in uremia. FEBS Lett 1998; 427: 381-385

[94] Nakamura K, Nakazawa Y, lenaga K. Acid-stable fluorescent advanced glycation end products: vesperlysines $A, B$, and $C$ are formed as crosslinked products in the maillard reaction between lysine or proteins with glucose. Biochem Biophys Res Commun 1997; 232: 227-230

[95] Brownlee M, Vlassara H. Aminoguanidine prevents diabetes-induced arterial wall protein cross-linking. Sci New Ser 1986; 232: 1629-1632

[96] Thornalley P, Yurek-George A, Argirov O. Kinetics and mechanism of the reaction of aminoguanidine with the $\alpha$-oxoaldehydes glyoxal, methylglyoxal, and 3-deoxyglucosone under physiological conditions. Biochem Pharmacol 2000; 60: 55-65

[97] Borg D, Forbes J. Targeting advanced glycation with pharmaceutical agents: where are we now? Glycoconj J 2016; 33: 653-670

[98] Nagai R, Murray D, Metz T, Baynes J. Chelation: a fundamental mechanism of action of AGE inhibitors, AGE breakers, and other inhibitors of diabetes complications. Diabetes 2012; 61: 549-559

[99] Sadowska-Bartosz I, Bartosz G. Prevention of protein glycation by natural compounds. Molecules 2015; 20: 3309-3334

[100] Khalifah R, Voziyan P, Serianni A, Jacob J, Thibaudeau C, Yildiz A, Hudson $B$. Modification of proteins in vitro by physiological levels of glucose. J Biol Chem 2003; 278: 46616-46624

[101] Nagaraj R, Sarkar P, Mally A, Biemel K, Lederer M, Padayatti P. Effect of pyridoxamine on chemical modification of proteins by carbonyls in diabetic rats: characterization of a major product from the reaction of pyridoxamine and methylglyoxal. Arch Biochem Biophys 2002; 402: 110-119

[102] Pagnozzi F, Bena E, Beltramo E, Molinatti P, Molinatti G, Porta M, Selva M. Thiamine corrects delayed replication and decreases production of lactate and advanced glycation endproducts in bovine retinal and human umbilical vein endothelial cells cultured under high glucose conditions. Diabetologia 2002; 39: 1263-1268

[103] Hamada Y, Nakamura J, Naruse K, Komori T, Kato K, Kasuya Y, Nagai R, Horiuchi S, Hotta N. Epalrestat, an aldose reductase inhibitor, reduces the levels of $\mathrm{N}(\varepsilon)$-(carboxymethyl)lysine protein adducts and their precursors in erythrocytes from diabetic patients. Diabetes Care 2000; 23 : 1539-1544
[104] Touchette A, Szwergold B, Lal S, Beisswenger P, Howell S. Metformin reduces systemic methylglyoxal levels in type 2 diabetes. Diabetes 1999; 48: 198-202

[105] Daniel R, Lecomte M, Lagarde M, Wiernsperger N. Reaction of metformin with dicarbonyl compounds. Possible implication in the inhibition of advanced glycation end product formation. Biochem Pharmacol 1999; 58: 1765-1773

[106] Miyata T, Van Ypersele de Strihou C, Ueda Y, Ichimori K, Inagi R, Onog H, Ishikawa N, Nangaku M, Kurokawa K. Angiotensin II receptor antagonists and angiotensin-converting enzyme inhibitors lower in vitro the formation of advanced glycation end products: Biochemical mechanisms. J Am Soc Nephrol 2002; 13: 2478-2487

[107] Forbes ], Cooper M, Thallas V, Burns W, Thomas M, Brammar G, Lee F, Grant S, Burrell L, Jerums G, Osicka T. Reduction of the accumulation of advanced glycation endproducts by ACE inhibition in experimental diabetic nephropathy. Blood Press 2002; 51: 3274-3282

[108] May J, Qu Z. Troglitazone protects human erythrocytes from oxidant damage. Antioxidants Redox Signal 2000; 2: 243-250

[109] Chompoo J, Upadhyay A, Kishimoto W, Makise T, Tawata S. Advanced glycation end products inhibitors from Alpinia zerumbet rhizomes. Food Chem 2011; 129: 709-715

[110] Li C, Tan F, Yang J, Yang Y, Gou Y, Li S, Zhao X. Antioxidant effects of Apocynum venetum tea extracts on $\mathrm{D}$-Galactose-induced aging model in mice. Antioxidants 2019; 8: 1-16

[111] Yokozawa T, Nakagawa T. Inhibitory effects of Luobuma tea and its components against glucose-mediated protein damage. Food Chem Toxicol 2004; 42: 975-981

[112] Motomura K, Fujiwara Y, Kiyota N, Tsurushima K, Takeya M, Nohara T Nagai R, Ikeda T. Astragalosides isolated from the root of astragalus radix inhibit the formation of advanced glycation end products. J Agric Food Chem 2009; 57: 7666-7672

[113] Ahmad H, Khan I, Wahid A. Antiglycation and antioxidation properties of Juglans regia and Calendula officinalis: possible role in reducing diabetic complications and slowing down ageing. J Tradit Chinese Med 2012; 32: 411-414

[114] Shakthi A, Sathish T, Kumaresan K, Rapheal V. Extraction process optimization of polyphenols from Indian Citrus sinensis as novel antiglycative agents in the management of diabetes mellitus. J Diabetes Metab Disord 2014; 13: 1-10

[115] Ramful D, Tarnus E, Rondeau P, Da Silva C, Bahorun T, Bourdon E. Citrus fruit extracts reduce advanced glycation end products (AGEs)and $\mathrm{H} 2 \mathrm{O} 2$-induced oxidative stress in human adipocytes. J Agric Food Chem 2010; 58: 11119-11129

[116] Liu J, Feng L, Zhu M, Wang R, Zhang M, Hu S, Jia X, Wu J. The in vitro protective effects of curcumin and demethoxycurcumin in Curcuma longa extract on advanced glycation end products-induced mesangial cell apoptosis and oxidative stress. Planta Med 2012; 78: 1757-1760

[117] Adaramoye O, Anjos R, Almeida M, Veras R, Silvia D, Oliveira F, Cavalcante K, Araújo I, Oliveira A, Medeiros I. Hypotensive and endothelium-independent vasorelaxant effects of methanolic extract from Curcuma longa L. in rats. J Ethnopharmacol 2009; 124: 457-462

[118] Harris C, Cuerrier A, Lamont E, Haddad P, Arnason J, Bennett S, Johns T. Investigating wild berries as a dietary approach to reducing the formation of advanced glycation endproducts: chemical correlates of in vitro antiglycation activity. Plant Foods Hum Nutr 2014; 69: 71-77

[119] Siddiqui M, Rasheed S, Saquib Q, Al-Khedhairy A, Al-Said M, Musarrat ], Choudhary M. In vitro dual inhibition of prontein glycation, and oxidation by some Arabian plants. BMC Complement Altern Med 2016; 16: $1-11$

[120] Abbas G, Hassan M, Saddiqe Z, Shahzad M. Non-toxic fractions of Hypericum perforatum and Hypericum oblongifolium inhibit protein glycation, free radicals production and lipid peroxidation in vitro. Int J Phytomedicine 2013; 5: 191-196 
[121] Yoo N, Jang D, Lee Y, Jeong I, Cho J, Kim J, Kim J. Anthraquinones from the roots of Knoxia valerianoides inhibit the formation of advanced glycation end products and rat lens aldose reductase in vitro. Arch Pharm Res 2010; 33: 209-214

[122] Hwang S, Wang Z, Quispe Y, Lim S, Yu J. Evaluation of aldose reductase, protein glycation, and antioxidant inhibitory activities of bioactive flavonoids in Matricaria recutita L. and their structure-activity relationship. J Diabetes Res 2018; 2018: 1-11

[123] Yui S, Fujiwara S, Harada K, Motoike-Hamura M, Sakai M, Matsubara S, Miyazaki K. Beneficial effects of lemon balm leaf extract on in vitro glycation of proteins, arterial stiffness, and skin elasticity in healthy adults. J Nutr Sci Vitaminol (Tokyo) 2017; 63: 59-68

[124] Tupe R, Sankhe N, Shaikh S, Kemse N, Khaire A, Phatak D, Parikh J. Nutraceutical properties of dietary plants extracts: Prevention of diabetic nephropathy through inhibition of glycation and toxicity to erythrocytes and HEK293 cells. Pharm Biol 2015; 53: 40-50

[125] Pandey R, Kumar D, Ali A. Nigella sativa seed extracts prevent the glycation of protein and DNA. Curr Perspect Med Aromat Plants 2018; 1: $1-7$

[126] Chen W, Balan P, Popovich D. Review of ginseng anti-diabetic studies. Molecules 2019; 24: 1-16

[127] Lv L, Cheng Y, Zheng T, Li X, Zhai R. Purification, antioxidant activity and anti-glycation of polysaccharides from Polygonum multiflorum Thunb. Carbohydr Polym 2014; 99: 765-773

[128] Kumagai Y, Nakatani S, Onodera H, Nagatomo A, Nishida N, Matsuura Y, Kobata K, Wada M. Anti-glycation effects of pomegranate (Punica granatum L.) fruit extract and its components in vivo and in vitro. J Agric Food Chem 2015; 63: 7760-7764

[129] Di Sotto A, Locatelli M, Macone A, Toniolo C, Cesa S, Carradori S, Eufemi M, Mazzanti G, Di Giacomo S. Hypoglycemic, antiglycation, and cytoprotective properties of a phenol-rich extract from waste peel of Punica granatum L. Var. Dente di cavallo DC2. Molecules 2019; 24: $1-22$

[130] Lee E, Song D, Lee J, Pan C, Um B, Jung S. Inhibitory effect of the compounds isolated from Rhus verniciflua on aldose reductase and advanced glycation endproducts. Biol Pharm Bull 2008; 31: 1626-1630

[131] Kiho T, Usui S, Hirano K, Aizawa K, Inakuma T. Tomato paste fraction inhibiting the formation of advanced glycation end-products. Biosci Biotechnol Biochem 2004; 68: 200-205

[132] Abeysekera W. Anti-glycation and glycation reversing potential of fenugreek (Trigonella foenum-graecum) seed extract. Biomed J Sci Tech Res 2018; 3: 3138-3142

[133] Ferrier J, Djeffal S, Morgan H, van der Kloet S, Redžić S, Cuerrier A, Balick M, Arnason J. Antiglycation activity of Vaccinium spp. (Ericaceae) from the Sam Vander Kloet collection for the treatment of type II diabetes1. Botany 2012; 90: 401-406

[134] Jariyapamornkoon N, Yibchokanun S, Adisakwattana S. Inhibition of advanced glycation end products by red grape skin extract and its antioxidant activity. BMC Complement Altern Med 2013; 13: 1-9

[135] Shen Y, Xu Z, Sheng Z. Ability of resveratrol to inhibit advanced glycation end product formation and carbohydrate-hydrolyzing enzyme activity, and to conjugate methylglyoxal. Food Chem 2017; 216: 153160

[136] Asumoto A, Kimoto U, Obori A. Dietary phloridzin reduces blood glucose levels and reverses Sglt1 expression in the small intestine in streptozotocin-induced diabetic mice. J Agric Food Chem 2009; 24: 46514656

[137] Zielinska D, Laparra-Llopis J, Zielinski H, Szawara-Nowak D, GiménezBastida J. Role of apple phytochemicals, phloretin and phloridzin, in modulating processes related to intestinal inflammation. Nutrients 2019; 11: 1-14

[138] Cao X, Xia Y, Zeng M, Wang W, He Y, Liu J. Caffeic acid inhibits the formation of advanced glycation endproducts (AGEs) and mitigates the
AGEs-induced oxidative stress and inflammation reaction in human umbilical vein endothelial cells (HUVECs). Chem Biodivers 2019; 16: $1-20$

[139] Raghu G, Jakhotia S, Yadagiri Reddy P, Kumar PA, Bhanuprakash Reddy G. Ellagic acid inhibits non-enzymatic glycation and prevents proteinuria in diabetic rats. Food Funct 2016; 7: 1574-1583

[140] Muthenna P, Akileshwari C, Reddy B. Ellagic acid, a new antiglycating agent: Its inhibition of $\mathrm{N} \varepsilon$-(carboxymethyl)lysine. Biochem J 2012; 442: $221-230$

[141] Huang S, Hsu C, Chuang H, Shih P, Wu C, Yen G. Inhibitory effect of vanillic acid on methylglyoxal-mediated glycation in apoptotic Neuro2A cells. Neurotoxicology 2008; 29: 1016-1022

[142] Kim J, Jeong I, Kim C, Lee Y, Kim J, Kim J. Chlorogenic acid inhibits the formation of advanced glycation end products and associated protein cross-linking. Arch Pharm Res 2011; 34: 495-500

[143] Sompong W, Cheng H, Adisakwattana S. Ferulic acid prevents methylglyoxal-induced protein glycation, DNA damage, and apoptosis in pancreatic $\beta$-cells. J Physiol Biochem 2017; 73: 121-131

[144] Ramu R, Shirahatti P, Zameer F, Ranganatha L, Nagendra Prasad MN. Inhibitory effect of banana (Musa sp. var. Nanjangud rasa bale) flower extract and its constituents umbelliferone and lupeol on $\alpha$-glucosidase, aldose reductase and glycation at multiple stages. South African J Bot 2014; 95: 54-63

[145] Shay J, Elbaz H, Lee I, Zielske S, Malek M, Hüttemann M. Molecular mechanisms and therapeutic effects of (-)-epicatechin and other polyphenols in cancer, inflammation, diabetes, and neurodegeneration. Oxid Med Cell Longev 2015; 2015: 1-13

[146] Wu X, Zhang G, Hu X, Pan J, Liao Y, Ding H. Inhibitory effect of epicatechin gallate on protein glycation. Food Res Int 2019; 122: 230240

[147] Rasheed Z, Anbazhagan A, Akhtar N, Ramamurthy S, Voss F, Haqqi T. Green tea polyphenol epigallocatechin-3-gallate inhibits advanced glycation end product-induced expression of tumor necrosis factor- $\alpha$ and matrix metalloproteinase-13 in human chondrocytes. Arthritis Res Ther 2009; 11: 1-13

[148] Zhou Q, Cheng K, Gong J, Li E, Wang M. Apigenin and its methylglyoxal-adduct inhibit advanced glycation endproducts-induced oxidative stress and inflammation in endothelial cells. Biochem Pharmacol 2019; 166: 231-241

[149] Pari L, Srinivasan S. Antihyperglycemic effect of diosmin on hepatic key enzymes of carbohydrate metabolism in streptozotocin-nicotinamideinduced diabetic rats. Biomed Pharmacother 2010; 64: 477-481

[150] Peng X, Zheng Z, Cheng K, Shan F, Ren G, Chen F, Wang M. Inhibitory effect of mung bean extract and its constituents vitexin and isovitexin on the formation of advanced glycation endproducts. Food Chem 2008; 106: 475-481

[151] Liu J, Yang Z, Cheng Y, Wu Q, He Y, Li Q, Cao X. Eriodictyol and naringenin inhibit the formation of AGEs: an in vitro and molecular interaction study. J Mol Recognit 2020; 33: 1-7

[152] Zhang X, Song Y, Han X, Feng L, Wang R, Zhang M, Zhu M, Jia X, Hu S. Liquiritin attenuates advanced glycation endproducts-induced endothelial dysfunction via RAGE/NF-KB pathway in human umbilical vein endothelial cells. Mol Cell Biochem 2013; 374: 191-201

[153] Zhang Z, Sethiel M, Shen W, Liao S, Zou Y. Hyperoside downregulates the receptor for advanced glycation endproducts (RAGE) and promotes proliferation in ECV304 cells via the c-Jun N-terminal kinases (JNK) pathway following stimulation by advanced glycation end-products in vitro. Int J Mol Sci 2013; 14: 22697-22707

[154] Urios P, Grigorova-Borsos AM, Sternberg M. Flavonoids inhibit the formation of the cross-linking AGE pentosidine in collagen incubated with glucose, according to their structure. Eur J Nutr 2007; 46: 139-146

[155] Li Y, Ding Y. Minireview: therapeutic potential of myricetin in diabetes mellitus. Food Sci Hum Wellness 2012; 1: 19-25 
[156] Thilavech T, Ngamukote S, Belobrajdic D, Abeywardena M, Adisakwattana S. Cyanidin-3-rutinoside attenuates methylglyoxal-induced protein glycation and DNA damage via carbonyl trapping ability and scavenging reactive oxygen species. BMC Complement Altern Med 2016; 16: $1-10$

[157] Costantino S, Paneni F, Lüscher T, Cosentino F. Pin1 inhibitor Juglone prevents diabetic vascular dysfunction. Int J Cardiol 2016; 203: 702707

[158] Liu W, Cai A, Carley R, Rocchio R, Petrovas Z, Chartier C, Meng X, Su J, Cho B, Dain J, Ma H, Seeram N. Bioactive anthraquinones found in plant foods interact with human serum albumin and inhibit the formation of advanced glycation endproducts. J Food Bioact 2018; 4: 130138

[159] Btissam R, Rajae R, Amina A, Brigitte V, Mohamed N. In vitro study of anti-glycation and radical scavenging activities of the essential oils of three plants from Morocco: Origanum compactum, Rosmarinus officinalis and Pelargonium asperum. Pharmacogn J 2015; 7: 124-135

[160] Zhou P, Xie W, He S, Sun Y, Meng X, Sun G, Sun X. Ginsenoside Rb1 as an anti-diabetic agent and its underlying mechanism analysis. Cells 2019; 8: 204

[161] Ding H, Ni M, Zhang G, Liao Y, Hu X, Zhang Y, Gong D. The inhibition of oleanolic acid on protein non-enzymatic glycation. LWT Food Sci Technol 2020; 125: 109253

[162] Yin M. Inhibitory effects and actions of pentacyclic triterpenes upon glycation. Biomed 2015; 5: 1-8

[163] Hao M, Li S, Sun C, Jingyu-Xu, Lin Y, Liu KX, Wang L, Li C, Zhou Q, Du J, $\mathrm{Li}$ H. Amelioration effects of berberine on diabetic microendothelial injury model by the combination of high glucose and advanced glycation end products in vitro. Eur J Pharmacol 2011; 654: 320-325 